\title{
A Multiregional Input-Output Analysis of Water Withdrawals in the Southeastern United States*
}

\author{
Di Sheng, ${ }^{a}$ Stephanie Owen, ${ }^{\mathrm{b}}$ Dayton M. Lambert, ${ }^{\mathrm{c}}$ \\ Burton C. English, ${ }^{\mathrm{d}}$ Robert J. Menard, ${ }^{\mathrm{d}}$ David W. Hughes, ${ }^{\mathrm{d}}$ \\ Lixia He-Lambert, ${ }^{\mathrm{c}}$ and Christopher D. Clark $^{\mathrm{d}}$ \\ ${ }^{a}$ Department of Agricultural and Resource Economics, Colorado State University, USA \\ ${ }^{b}$ US Army Engineer District, USA \\ ${ }^{c}$ Department of Agricultural Economics, Oklahoma State University, USA \\ ${ }^{d}$ Department of Agricultural and Resource Economics, University of Tennessee, USA
}

\begin{abstract}
The amount of water withdrawn to support economic activity in the southeastern United States is estimated using a multiregional Environmental Input-Output/Life Cycle Analysis model. Water multipliers are measured as gallons of water withdrawn to meet a one-dollar increase in a commodity's final demand. The analysis finds that direct and indirect water withdrawal requirements embedded in the production of goods and services is heterogeneous across the study region. The utilities and crop production sectors exhibit the largest water multipliers. For an increase in final demand for crop production, direct regional effects contribute more to water multipliers compared to contributions from inter-regional and intersectoral sources. Alternatively, regional and inter-sectoral multipliers contribute more to the composition of the utilities sectors' water multipliers. The resulting water footprint could inform the design of water management policies for local, state, and regional institutions, including markets for water.

keywords: life cycle analysis, environmental input-output, multi-regional, water use, Southeastern U.S.

JEL Codes: Q25, C67

${ }^{*}$ This research was supported by the USDA National Institute of Food and Agriculture's (NIFA) Agriculture and Food Research Initiative (AFRI) Competitive Grant Nos. \# 2014-08253 and \# 2012-67009-19706, the Tennessee Agricultural Experiment Station, and NIFA Hatch Multistate Project NE-1749. The findings and views expressed in this study are those of authors.

Sheng is a student at Colorado State University, Fort Collins, CO, 80523. Owen is a researcher at U.S. Army Corps of Engineers, Nashville, TN, 37203. Lambert is a Professor and the Willard Sparts Chair of Agribusiness at Oklahoma State University, Stillwater, OK, 74078. English is a Professor of Agriculture and Resource Economics at the University of Tennessee, Knoxville, TN, 37916. Menard is a researcher at the University of Tennessee, Knoxville, TN, 37916. Hughes is a Professor of Agriculture and Resource Economics at the University of Tennessee. He-Lambert is an Assistant Professor at Oklahoma State University, Stillwater, OK, 74078. Clark is a Professor of Agriculture and Resource Economics at the University of Tennessee, Knoxville, TN, 37916. Corresponding Author: D. M. Lambert, E-mail: dayton.lambert@okstate.edu
\end{abstract}




\section{Figure 1: Metropolitan Growth in the Southeastern U.S.}

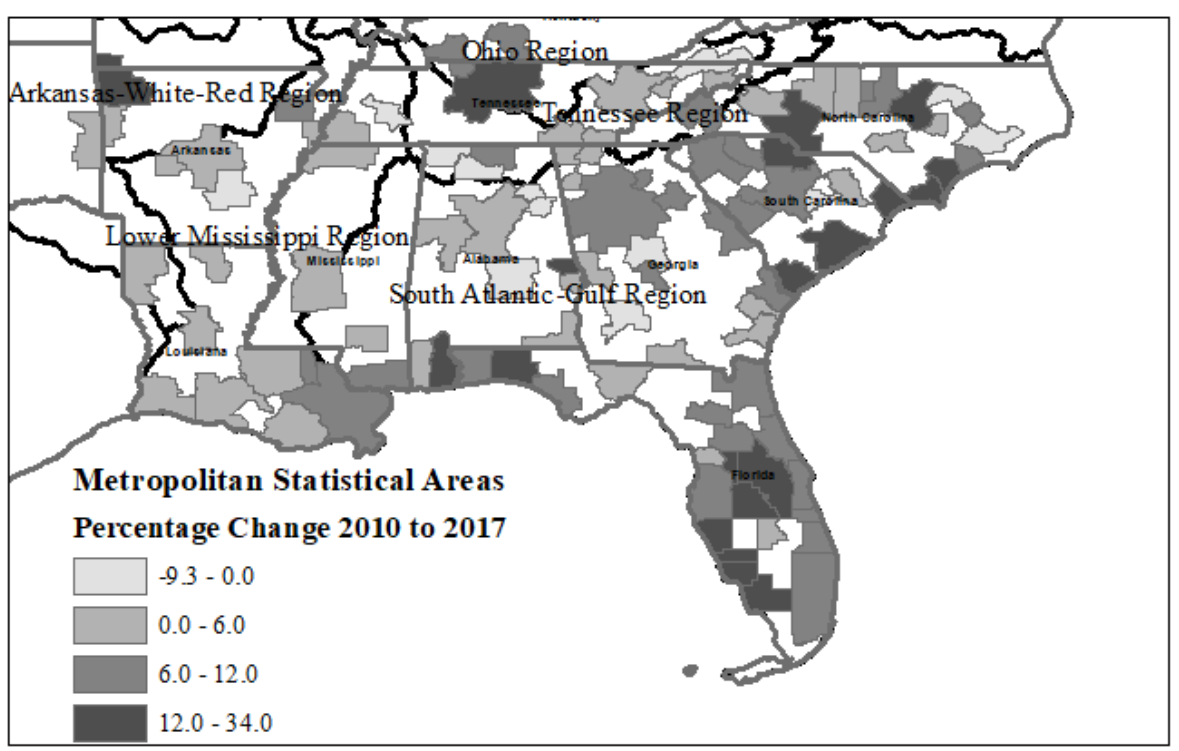

\section{INTRODUCTION}

The southeastern United States (U.S.) is undergoing rapid population growth. From 2010 to 2017, the population of the southeastern U.S. (defined here as the states of Alabama, Arkansas, Florida, Georgia, Louisiana, Mississippi, North Carolina, South Carolina, and Tennessee) grew by 7.9 percent, while the population of the rest of the nation grew by 4.8 percent (U.S. Census Bureau, 2017). From 2011 to 2016, the population growth rate for the $75^{\text {th }}$ percentile of the nation's 382 metropolitan statistical areas (MSA) ranged between 6.98 percent (Idaho Falls, ID) and 32.78 percent (The Villages, FL) (United States Office of Management and Budget, 2016). The Office of Management and Budget defines an MSA as one or more adjacent counties with at least one urban core area population of at least 50,000 and adjacent areas with a strong social and economic links to the core economy (OMB Bulletin No.15-01, 2015). Of the 97 MSAs in this percentile, 27 were in the Southeast Atlantic, Gulf Coast, and Tennessee basin, a region draining into the Gulf of Mexico and the Atlantic (Hoos et al., 2013). Taken together, population in the MSAs of this region has increased by 11.34 percent since 2011 (base, 24.48 million). Within the region, the fastest growing areas are located in Florida, along the coasts (except Louisiana) and in the headwaters of the South Atlantic-Gulf basin.

The southeast U.S.' rapid growth brings with it increased burden on the region's ground and surface water resources and conflict over their use. Georgia, Alabama, and Florida have been battling over water use for decades (Southern Environmental Law Center, 2017). The up-stream user, Georgia, has continuously increased its water withdrawals to support the Atlanta metropolitan region. Water withdrawals for Atlanta increased from 275 to 360 million gallons per day, matched by an 80 percent increase in population from 1992 to 2013 (Hawkins, 2016). Alabama and Florida lawmakers questioned Georgia's water management, 
concerned that Atlanta's growing demand for water would limit the region's future water availability.

Several lawsuits resulted, leading to the "Tri-State Water Wars" (Southern Environmental Law Center, 2008). In 2018, the Georgia legislation passed a resolution calling on Tennessee, Georgia, and North Carolina lawmakers to resolve a 200-year dispute over state borders (Gross, 2018). Moving the Tennessee-Georgia border one-mile north would give Georgia access to the Tennessee River and as much as 500 million gallons of water per day for Northern Georgia and Atlanta (Mojica, 2018). In 2016, Mississippi filed a \$615-million lawsuit against the City of Memphis, Tennessee for allegedly pumping 140 million gallons per day over 20-plus years from the Memphis Sands Aquifer; an aquifer claimed by Mississippi.

In 2000, average water withdrawn from the Tennessee Valley system was 12,211 million gallons per day $\left(\mathrm{Mgal} \mathrm{d}^{-1}\right.$ ) (Hutson et al., 2004). By 2010, the total of water withdrawn from the system decreased by 2.1 percent to 11,951 $\mathrm{Mgal} \mathrm{d}^{-1}$ (Bohac and Bowen, 2012). Yet, Bohac and Bowen (2012) project that, while total water withdrawal in the Tennessee Valley will decrease by 21 percent by 2035 (due to the introduction of closed-cycle cooling technology for power generation), water use by industries will increase by 31 percent. All else equal, net consumptive water use in the Tennessee Valley is expected to increase by 51 percent (Bohac and Bowen, 2012). Recent trends in the agricultural sector suggest too an expansion of irrigated acres. From 2002 to 2012, the region's irrigated acres increased by 13 percent to 10.83 million (U.S. Department of Agriculture, 2013).

The stress on water resources and the institutions and systems that allocate and distribute water is likely to be further exacerbated by climate change. Across the southeastern region, average temperatures and the number of days of extreme heat are projected to increase (Vose et al., 2017). While total precipitation is also projected to increase, increases in the number of extreme rainfall events and changes in seasonal precipitation patterns may offset its positive effects on water availability (Easterling et al., 2017). Another effect of climate change on the southeast will be to move people "upstream." Retirees migrating from coastal areas inland to avoid hurricanes and higher insurance premiums could end up in rural areas with limited water resources (Park et al., 2007). In response, rural communities that continue to attract retirees will need to develop long-term plans to address increased demand for limited water resources and utility infrastructure in their communities (Mullinix, 2014).

These trends fuel dialogue among state officials, media, and research institutions concerning water use rights, water conservation, the economic value of water, and opportunities for water trading. However, perceived abundance in water resources makes planning for scarcity challenging. Solutions may require socially or politically undesirable trade-offs. Framing trade-offs requires a transdisciplinary understanding of the stock and flow of water across geographic boundaries and social institutions, as well as through the economy. In economic terms, water use efficiency implies that competitive markets allocate water to productive factors such that the marginal value of production from use of the factor equals the cost of providing the water, including any associated opportunity costs. Adaptive planning requires understanding these trade-offs.

This research uses an Environmental Input-Output/Life Cycle Analysis model (EIOLCA) to characterize the water footprint of the southeast U.S. economy. Data from the Economic Impact for Planning (IMPLAN) database (IMPLAN, 2013) and county-level water

(C)Southern Regional Science Association 2019. 
withdrawals from the United States Geological Survey (Maupin et al., 2014) are used to estimate water multipliers - defined as the gallons required to meet a one-dollar increase in final demand - for 21 aggregated sectors across 43 Bureau of Economic Analysis (BEA) regions (Table 1).

The analysis provides a snapshot of the flow of water through the region's economy; not only across economic sectors but also between sub-regions (here, BEAs) because the InputOutput component of the LCA is augmented to account for inter-regional transactions. The resulting water multipliers, based on water withdrawals and economic production, therefore indicate the relative magnitude of use between sectors but also across regions. The analysis indicates that direct and indirect water requirements embedded in the production of goods and services are heterogeneous across the study region. The largest multipliers are associated with primary agricultural production activities and energy production and distribution. The interregional analysis of the region's water footprint could inform local and regional policy on water management and potentially provide a starting point from which to model water transfer between economic sectors and regions.

\section{BACKGROUND}

Water availability has not historically received the attention in the southeastern U.S. that it has in the arid west. However, demands on the region's water resources continue to increase due to expansion in irrigated acres for agriculture, increasing urbanization, and sustained population and economic growth (McNulty et al., 2007; Seager et al., 2009). Limited storage capacity, an aging urban infrastructure, and the reliance of large inland population centers on relatively small watersheds with constrained water supplies pose challenges. However, the degree to which each of these factors challenge resiliency varies regionally. Climate change could exacerbate anthropogenic stressors, with increasing uncertainty in rainfall patterns punctuated by more frequent occurrences of extreme droughts, storm events, and wildfires (Melillo, 2014). Indeed, the frequency of billion-dollar disaster events is highest in the midwestern and southern states (Smith and Katz, 2013). This concentration may result from the interaction of physical features (e.g. topography and proximity to warm shallow water bodies, like the Gulf) with population centers and land use (e.g., crop and livestock agriculture).

In regional economies with hundreds of economic sectors, the issue of allocating scarce resources according to an efficiency criterion is even more complicated. It is important to understand the interconnections between water flow and financial externalities in the event of unforeseen disruptions or for containing and managing the costs of growth in terms of sustaining or increasing water use capacity. Inter-sectoral linkages define an economy's structure through transactions as purchases and sales. Transactions occur between sectors in a region, but also with neighboring regions. There is also scale incongruence between jurisdictions, the scope of regulating institutions managing stocks, and the natural features of the hydrological system governing water flow. A shortage of water in one sector may indirectly affect delivery to final demand points. For example, Blackhurst et al. (2010) found that 60 percent of water withdrawals by 428 U.S. sectors was used indirectly (e.g., "embodied" in the production of goods and services). The same authors also estimated 
Table 1: Aggregation of Economic Sectors

\begin{tabular}{|c|c|}
\hline Aggregated sector & Economic sectors in aggregation \\
\hline Crop & $\begin{array}{l}\text { Farming of oilseed, grain, vegetable and melon, fruit, tree nut, tobacco, } \\
\text { cotton, sugarcane and sugar beet, and all other crops; production of green- } \\
\text { house, nursery, and floriculture; supportive activities for agricultural and } \\
\text { forestry }\end{array}$ \\
\hline Livestock & $\begin{array}{l}\text { Ranching and farming of beef cattle; production of dairy and milk, poul- } \\
\text { try and egg, and other animal products; commercial fishing, hunting, and } \\
\text { trapping }\end{array}$ \\
\hline Forestry & Forestry, forest products, and timber tract production; commercial logging \\
\hline Mining & $\begin{array}{l}\text { All commercial mining and other nonmetallic minerals; drilling oil and gas } \\
\text { wells; supportive activities for oil and gas operation }\end{array}$ \\
\hline Services & All services \\
\hline Utilities & $\begin{array}{l}\text { Electric power generation, transmission and distribution; natural gas dis- } \\
\text { tribution }\end{array}$ \\
\hline Water and Sewage & Water, sewage, and other systems \\
\hline Construction & All constructions, maintenance and repair \\
\hline Secondary Agriculture & $\begin{array}{l}\text { Dog, cat, and other animal food manufacturing; milling and refining; malt, } \\
\text { malt, breakfast cereal, beet sugar manufacturing; soybean and other oilseed } \\
\text { processing; food, spice, drink, alcohol, fabric, textile, apparel manufacturing }\end{array}$ \\
\hline Other Manufacturing & $\begin{array}{l}\text { Non-food and non-fiber manufacturing (not including agricultural and } \\
\text { forestry input- or output-related manufacturing) }\end{array}$ \\
\hline $\begin{array}{l}\text { Primary Forest Product } \\
\text { Manufacture }\end{array}$ & Sawmill, woodworking, and paper machinery \\
\hline $\begin{array}{l}\text { Secondary Forestry Product } \\
\text { Manufacture }\end{array}$ & $\begin{array}{l}\text { Furniture, wood work manufacturing; and all other converted paper product } \\
\text { manufacturing }\end{array}$ \\
\hline $\begin{array}{l}\text { Food \& Fiber Products } \\
\text { Manufacture }\end{array}$ & $\begin{array}{l}\text { Lime, farm machinery and equipment, lawn and garden equipment manu- } \\
\text { facturing; fertilizer and pesticide and other agricultural chemical manufac- } \\
\text { turing }\end{array}$ \\
\hline Wholesale Trade & Wholesale trade \\
\hline Retail Trade & Dealers, retail stores \\
\hline Transportation & Air, rail, water, truck, transit and ground, pipeline, scenic and sightseeing \\
\hline Government & $\begin{array}{l}\text { Schools, junior colleges, colleges, universities, and professional schools; } \\
\text { local and federal electric utilities; transit, state and local government en- } \\
\text { terprises; local and federal employment and payroll of state and federal } \\
\text { government, rest of the world adjustment }\end{array}$ \\
\hline Finance & $\begin{array}{l}\text { Depository and non-depository credit intermediation; brokerage; financial } \\
\text { vehicles }\end{array}$ \\
\hline Insurance & Insurance carriers, agencies, brokerage, and related activities \\
\hline Real Estate & Real estate and owner-occupied dwellings \\
\hline Miscellaneous & $\begin{array}{l}\text { All others sectors (used goods, scrap, religious, business, and social organi- } \\
\text { zations) }\end{array}$ \\
\hline
\end{tabular}


that 96 percent of these 428 sectors used more water along their supply chains rather than directly in the final goods they produced. Water embodied in intermediate inputs could also be imported from other regions as 'virtual' transfers; i.e., the balance of water used in the production and distribution of a good to terminal demands (Norman et al., 2007; Zhao and Jackson, 2016; Mubako et al., 2013). Research also finds that there may be additional gains from trade when embodied water is included in transaction accounts (Chapagain et al., 2006). Quantifying the water embedded in the production and exchange of traded goods and services is a first step towards charting the complexity of interregional dependencies on limited water resources (Yang and Zehnder, 2007).

The EIO-LCA model applied here quantifies water multipliers using standard InputOutput (IO) procedures and sector transaction data. The application of the EIO-LCA model combines economic IO modeling with a water life cycle analysis to estimate the water withdrawals required from an economy's activities (Leontief, 1936; Hendrickson et al., 1998; Miller and Blair, 2009; Blackhurst et al., 2010; Egilmez et al., 2013). The EIO-LCA model uses information about industry transactions (purchases of materials by one industry from other industries), and data on the direct use of inputs used in the industry's production function to estimate the total resource requirements of the supply chain. EIO was originally designed to analyze the environmental footprint of macro-economies using national industry tables (Leontief, 1970; Cicas et al., 2007). All information pertaining to direct and indirect purchases required for production are embodied in the EIO part of the model. Appending resource (water) coefficient data to the EIO analysis generates the resource use impact (here, water withdrawal) of economic activities (Leontief, 1970). EIO-LCA is often considered an alternative representation of a product's life cycle (Hendrickson et al., 1998). Henry and Bowen (1981) applied this framework to determine the direct, indirect, and induced water withdrawn to meet increases in final demand for 64 sectors in South Carolina. Blackhurst et al. (2010) used EIO-LCA to determine the direct and indirect water used in 428 US industrial sectors.

This research augments a standard EIO-LCA model to accommodate trade between subregions using a Multi-Regional IO model (MRIO). Multiregional EIO-LCA models are not new, particularly regarding the analysis of water footprints and for assessing the potential for inter-regional water transfer. Many of the recent advances in the multi-regional EIOLCA methodology examine the embodied transfer of water in terms of goods and services in China. For example, Zhang and Anadon (2014) used a MRIO model to quantify economies of scale and the structure of inter-regional water trading, concluding that domestic transfers were double those occurring through internationally traded goods. Okadera et al. (2014) estimated the water footprints of fifteen provinces along the Yangtze River with a MRIO model. Their results indicated that regional water footprints, after assuming multi-regional transactions, were 11 percent larger than those estimated at an aggregate regional level. Zhao and Jackson (2016) examined the flow of water through traded goods and services at China's provincial level to increase water use efficiency through inter-provincial transfers. Zhuo et al. (2016a) developed a provincial-level MRIO model to quantify water footprints for crop production under historical climate and crop production variability. This model was extended in Zhuo et al. (2016b) to forecast water footprints for crop production under future climate scenarios. Chen et al. (2017) applied an MRIO model to analyze water transfer 
potential, and concluded that while the footprint was correlated with population centers, transfer patterns did not necessarily occur from water-abundant to water-poor regions. Water footprints have also been quantified using the multi-regional EIO-LCA method for Spain (Velázquez, 2006; Cazcarro et al., 2013) and the United Kingdom (Yu et al., 2010).

To the authors' knowledge, this is the first application of a multi-regional EIO-LCA for the southeastern U.S. We focus on identifying the structure and quantity of inter-regional transfers in terms of multipliers; i.e. the water requirement throughout the entire economy to satisfy one dollar's worth of final demand in that industry, for 21 sectors across 43 BEA regions.

\section{DATA AND METHODS}

Economic data on employment, regional production functions, final demand, and total industry output is from the IMPLAN (2013). The economic units of analysis were the Bureau of Economic Analysis functional regions. The Bureau of Economic Analysis uses the principal definition of MSAs to delineate economically integrated regions (Bureau of Economic Analysis, 2012). The economic sectors and corresponding direct requirement matrix for the $43 \mathrm{BEA}$ regions were assembled in IMPLAN. The 10 state region includes 763 counties. The 536 economic sectors IMPLAN uses were aggregated into 21 economic sectors according to Menard et al. (2013) (see Table 1). In 2013, the total value added (TVA) from economic activity in the region was $\$ 2.954$ trillion (IMPLAN, 2013). Most of the region's final demand was for services (32 percent), government ( 7 percent), real estate (6 percent), and manufacturing (9 percent) (see Figure 2). Atlanta, GA, Raleigh, NC, Charlotte, NC, Nashville, TN, and Miami, FL were the economic leaders in terms of total industry output, total value added, and employment.

The United States Geological Survey (USGS) periodically releases county-level water withdrawal (including both surface and ground water) estimates in $\mathrm{Mgal} \mathrm{day}^{-1}$ disaggregated to eight economic and demographic categories: public supply, domestic, irrigation, thermoelectric power, industrial, mining, livestock, and aquaculture (Maupin et al., 2014). The water used to produce goods in the region is generally inverse to the value added contributions to the economy (see Figure 3). For example, the relative contribution of the agricultural sector to the economy's gross regional production (value added) is small compared to the relative quantity of water used by the agricultural sector. Utilities, crop production, and livestock production comprise 88 percent of water withdrawal. A sizable portion of use was by BEA regions that are major energy and agricultural producers. For example, Little Rock, AR, Memphis, TN, and Huntsville, AL appear to be larger water users because of their dependency on either primary agriculture (e.g., livestock and crop production) and/or energy production and distribution.

There were 26,988 Ggal of water withdrawn in the 43 BEA regions in 2010 (see Table 2). Thermoelectric energy production accounted for 66 percent of total water withdrawal, while irrigated agriculture accounted for another 18 percent. Water withdrawn for irrigation was concentrated in the grains (21 percent of such withdrawal), oilseeds (40 percent), and greenhouse/nursery sectors (18 percent).

(C)Southern Regional Science Association 2019. 


\section{Figure 2: Total Value Added by Economic Sector and Region}

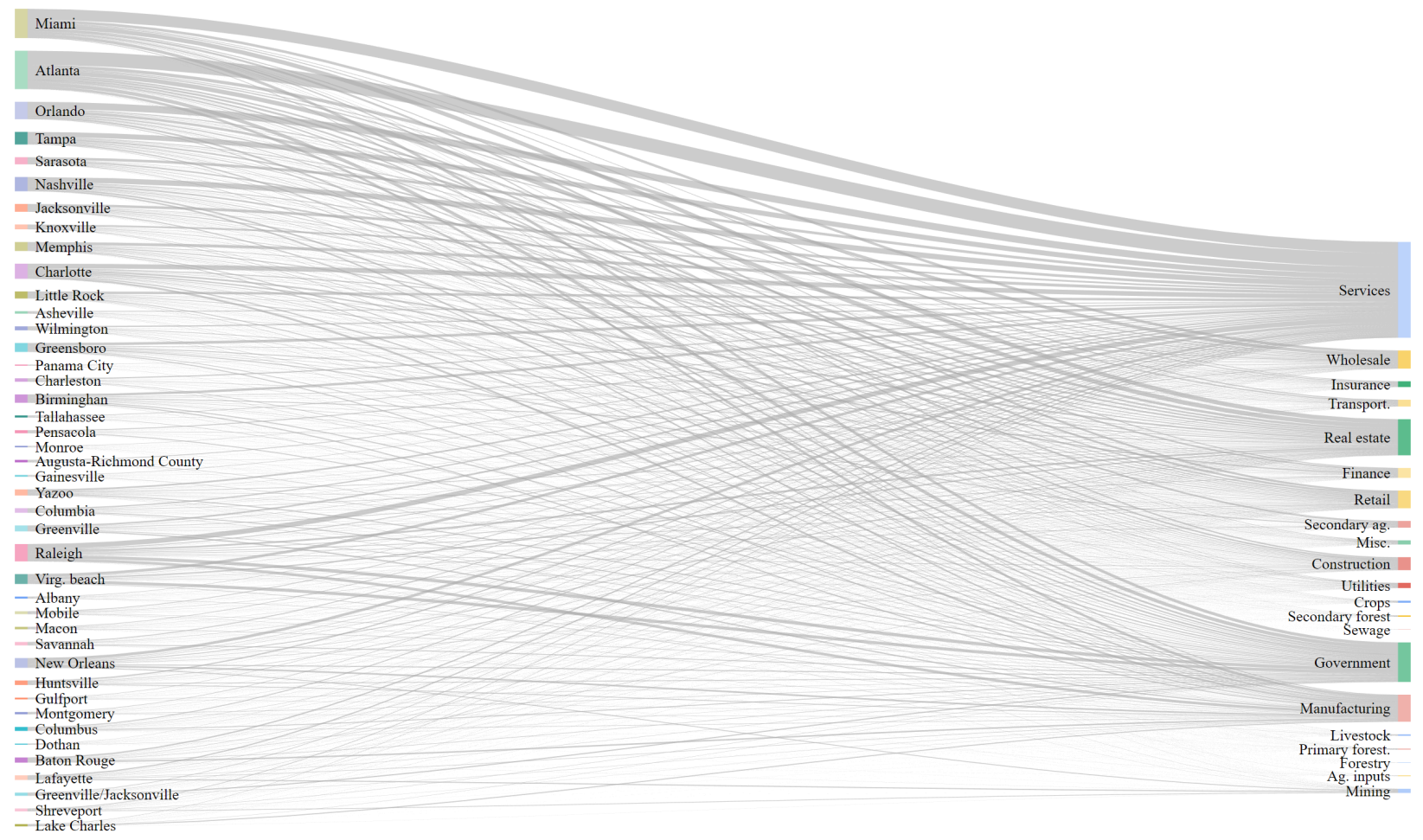

Source: IMPLAN Group, LLC (2013) and authors' calculations.

\subsection{Economic Input-Output Life-Cycle Analysis (EIO-LCA) and Water Mul- tipliers}

The objective of EIO-LCA analysis is to quantify the total impact of a change in industry output on an environmental indicator (Matthews et al., 2015). Changes in industry output are driven by changes in final demand for a good. Given a projected change in final demand, the direct and indirect requirements of industry output are determined. Direct water requirements are interpreted as "water use intensity", i.e. water used by the industry to produce one dollar's worth of industry output. Next, the environmental impacts of each sector (e.g., water use) are estimated. Finally, water use multipliers of all sectors can be aggregated to determine the total environmental impacts of an economic activity. The logic of this process is summarized in Figure 4.

Data from the USGS (Maupin et al., 2014) were used to derive water withdrawal by economic sectors in each BEA region. County-level water withdrawal data were aggregated up to BEA levels. County water use data were apportioned to BEAs based on area shares when BEA region boundaries intersected state boundaries. A downscaling method (Owen et al., 2017) was used to apportion USGS water withdrawal data from eight sector categories into 21 economic sectors (see Table 1). Technical details of the downscaling procedure and 


\section{Figure 3: Water Withdrawal by Economic Sector and Region}

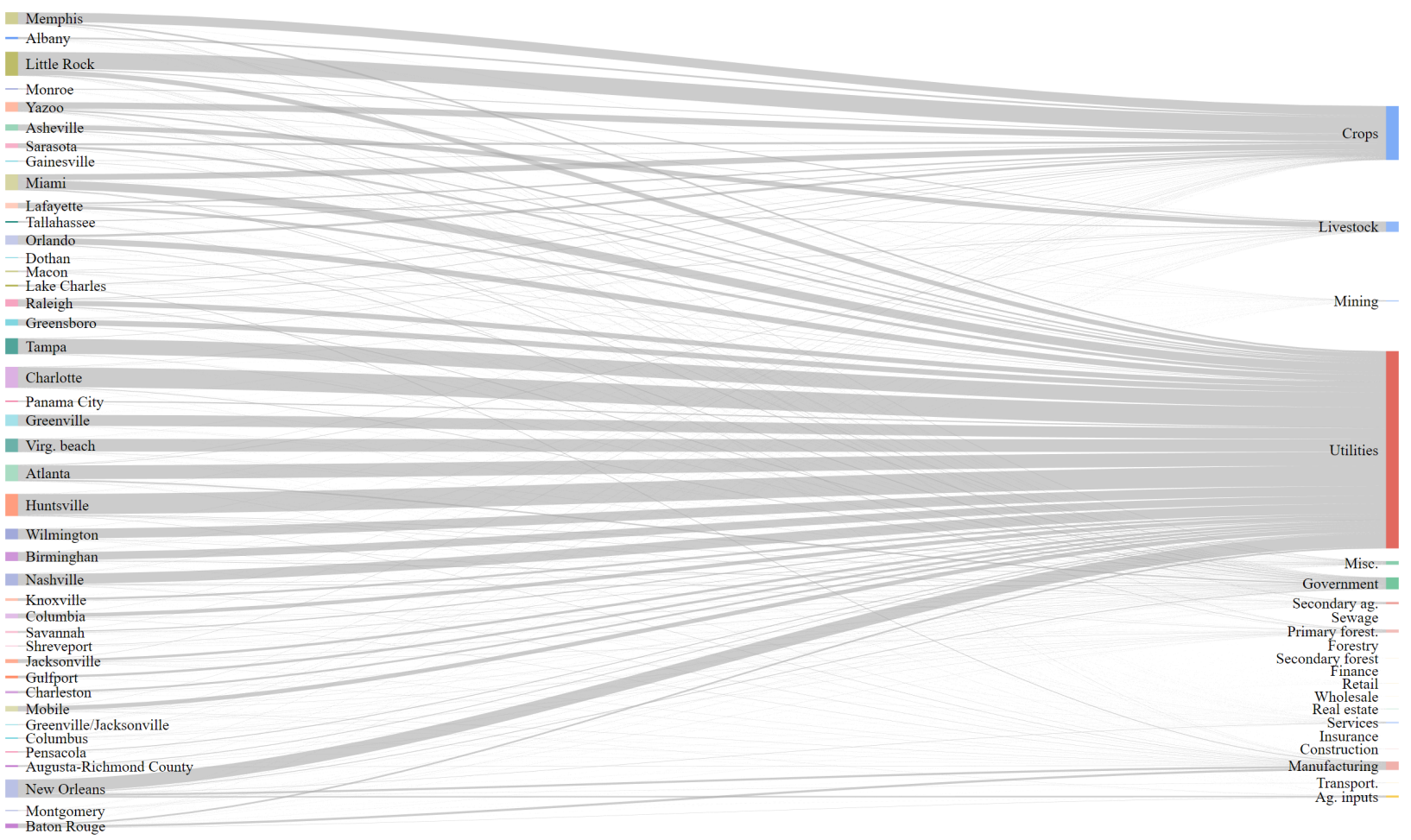

Source: United States Geological Survey (2014) and authors' estimates.

data sets are in Owen (2016). The direct requirements matrix for the 10-state region $(A)$ was obtained from the IMPLAN database. Employment (aggregated to the 21-sector model), total value added (final demand, $Y$ ), and total industry output (TIO, $X$ ) were estimated for each of the 43 BEA regions based on data from IMPLAN.

Water withdrawal coefficients $\left(W\right.$, in gallons $\$^{-1}$ units) were calculated for each sector in each BEA region (Appendix Table 1). Sector- and BEA-specific water withdrawal coefficients representing water withdrawals per dollar of TIO were calculated by dividing estimated water withdrawals by the TIO of a sector as $w_{i}^{r}=Q_{i}^{r} / X_{i}^{r}$, where $w_{i}^{r}, Q_{i}^{r}$ and $X_{i}^{r}$ denote the water withdrawal coefficient (gal $\${ }^{-1}$ ), total water withdrawal (gal), and TIO (\$), respectively, of sector $i=1,, 21$ and region $r=1,, 43$ (Hendrickson et al., 1998; Blackhurst et al., 2010; Chen et al., 2017). Following Matthews et al. (2015), the impact on water withdrawals generated from a change in final demand for any region $r$ is:

$$
\begin{gathered}
\Delta R^{r}=W^{r} \Delta X^{r} \\
\Delta X^{r}=\left(I-A^{r}\right)^{-1} \Delta Y^{r}
\end{gathered}
$$

where $\Delta R^{r}$ is the overall change in water withdrawal, subject to changes in total industry (c) Southern Regional Science Association 2019. 
Table 2: Total Water Withdrawal for the Region by Metropolitan Statistical Area, 2010

\begin{tabular}{|c|c|c|c|}
\hline BEA & Metropolitan Area, States & $\begin{array}{c}\text { Total Water } \\
\text { Withdrawal } \\
\text { (Ggal) }\end{array}$ & $\begin{array}{c}\text { Count of } \\
\text { sectors, } \\
\text { multiplier }> \\
\text { one }^{a}\end{array}$ \\
\hline 96 & Little Rock-North Little Rock-Pine Bluff, AR & 2174 & 16 \\
\hline 76 & Huntsville-Decatur, AL & 2032 & 21 \\
\hline 31 & Charlotte-Gastonia-Salisbury, NC-SC & 1910 & 21 \\
\hline 117 & New Orleans-Metairie-Bogalusa, LA & 1639 & 20 \\
\hline 11 & Atlanta-Sandy Springs-Gainesville, GA-AL & 1493 & 20 \\
\hline 164 & Tampa-St. Petersburg-Clearwater, FL & 1448 & 21 \\
\hline 106 & Miami-Fort Lauderdale-Miami Beach, FL & 1445 & 17 \\
\hline 173 & Virginia Beach-Norfolk-Newport News, VA-NC & 1218 & 21 \\
\hline 105 & Memphis, TN-MS-AR & 1092 & 20 \\
\hline 116 & Nashville-Davidson-Murfreesboro-Columbia, TN & 1078 & 21 \\
\hline 68 & Greenville-Spartanburg-Anderson, SC & 1038 & 21 \\
\hline 115 & Myrtle Beach-Conway-Georgetown, SC & 963 & 20 \\
\hline 80 & Jackson-Yazoo City, MS & 879 & 19 \\
\hline 121 & Orlando-The Villages, FL & 854 & 20 \\
\hline 19 & Birmingham-Hoover-Cullman, AL. & 819 & 21 \\
\hline 133 & Raleigh-Durham-Cary, NC & 668 & 21 \\
\hline 66 & Greensboro-Winston-Salem-High Point, NC & 578 & 21 \\
\hline 10 & Asheville-Brevard, NC & 567 & 20 \\
\hline 112 & Mobile-Daphne-Fairhope, AL & 498 & 19 \\
\hline 90 & Lafayette-Acadiana, LA & 496 & 19 \\
\hline 38 & Columbia-Newberry, SC & 434 & 20 \\
\hline 148 & Sarasota-Bradenton-Venice, FL & 428 & 20 \\
\hline 15 & Baton Rouge-Pierre Part, LA & 424 & 21 \\
\hline 79 & Jacksonville, FL & 353 & 20 \\
\hline 88 & Knoxville-Sevierville-La Follette, TN & 242 & 21 \\
\hline 69 & Gulfport-Biloxi-Pascagoula, MS & 239 & 19 \\
\hline 30 & Charleston-North Charleston, SC & 219 & 19 \\
\hline 3 & Albany, GA & 201 & 20 \\
\hline 149 & Savannah-Hinesville-Fort Stewart, GA & 172 & 20 \\
\hline 91 & Lake Charles-Jennings, LA & 165 & 19 \\
\hline 12 & Augusta-Richmond County, GA-SC & 152 & 21 \\
\hline 163 & Tallahassee, FL & 147 & 20 \\
\hline 123 & Panama City-Lynn Haven, FL & 128 & 20 \\
\hline 100 & Macon-Warner Robins-Fort Valley, GA & 125 & 21 \\
\hline 125 & Pensacola-Ferry Pass-Brent, FL & 115 & 21 \\
\hline 67 & Greenville, NC & 96 & 20 \\
\hline 113 & Monroe-Bastrop, LA & 91 & 21 \\
\hline 62 & Gainesville, FL & 83 & 21 \\
\hline 153 & Shreveport-Bossier City-Minden, LA & 80 & 21 \\
\hline 114 & Montgomery-Alexander City, AL & 60 & 20 \\
\hline 48 & Dothan-Enterprise-Ozark, AL & 57 & 21 \\
\hline 171 & Tupelo, MS & 55 & 21 \\
\hline 39 & Columbus-Auburn-Opelika, GA-AL & 33 & 20 \\
\hline
\end{tabular}

Source: United States Geological Survey (2014) and authors' estimates.

${ }^{a}$ Enumeration of sectors with a multiplier $>1$. 


\section{Figure 4: Data Sources and Modeling Logic}

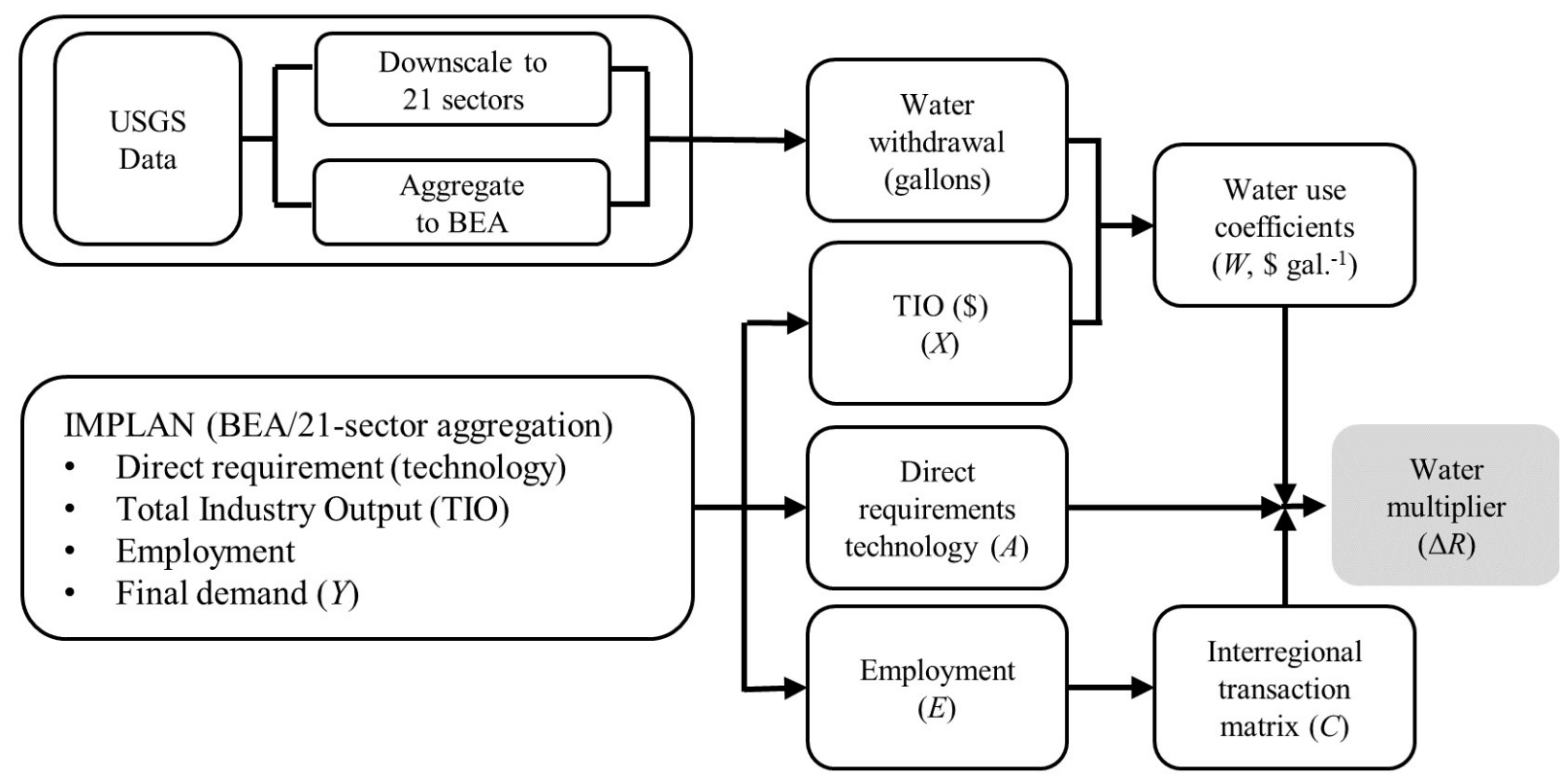

output, $\Delta X^{r} ; \Delta Y^{r}$ is the change in final demand; and $W^{r}=\operatorname{diag}\left(w_{i}^{r}\right)$ is a diagonal matrix of environmental burden coefficients (Leontief, 1970; Hendrickson et al., 2006; Matthews et al., $2015)$, i.e., the water use coefficients used here. The matrix $\left(I-A^{r}\right)^{-1}$ is the "Leontief inverse," indicating the direct and indirect purchase requirements for a given change in final demand, $\Delta Y^{r}$. The column sums of the inverted matrix are the water multipliers corresponding to a sector. These Type I multipliers quantify the amount of water withdrawn to meet a one-dollar increase in final demand for a good or service.

\section{2. $\quad$ EIO-LCA Multi-Regional Transactions}

This analysis uses Hewings et al. (2001)'s modification of the Chenery-Moses MRIO model and Polenske's calibration procedure to extend the EIO-LCA to a multi-regional inputoutput model. The key identity of this model sets total industry output in region $r$ (alias $s)$, sector $i$ (alias $j$ ) as:

$$
X_{i}^{r}=\sum_{s} \sum_{j} C T_{i}^{r s} \alpha_{i j}^{s} X_{j}^{s}+\sum_{s} C T_{i}^{r s} Y_{j}^{s}
$$

where $i(j)$ denotes a distributing (receiving) sector; $r(s)$ is an exporting (importing) region; $X$ is total industry output; and $Y$ is final demand. The elements of the multiregional direct requirements matrix are calculated by multiplying the column trade coefficients $\left(C T_{i}^{r s}\right)$ and the regional technical coefficients $\left(\alpha_{i j}^{s}\right)$ (Hewings et al., 2001; Miller and Blair, 2009). The column-trade coefficients are weights identifying region-sector pairs and the intensity of exchange between sub-regions and sectors; as the distance between regions increases, trade intensity decreases. The Euclidean distance between the centroids of the BEA polygons is 
used in this research. The dimension of the column-trade coefficient matrix $C$ is $(43 \times 21)$ by $(21 \times 43)$.

The multi-regional version of the EIO-LCA is similar in structure to the single region model, but augmented by including purchase and sales transactions through the matrix of regional trade coefficients, $C$. Miller and Blair (2009) summarize several methods to calculate the elements of $C$. Common approaches entail using location quotients ( $L Q \mathrm{~s})$, regional purchase coefficients, or other computationally intensive approaches with gravity models (Lindall et al., 2006; Robison et al., 2015). This analysis uses employment $L Q$ s to define interregional transactions (Hewings et al., 2001). The $L Q$ indicates a region's comparative advantage in its production capacity and its propensity to export goods from sector $i$ to other regions (Isserman, 1977, 1980).

Using $L Q \mathrm{~s}$, export shares for sector $i$, region $r\left(e x_{i}^{r}\right)$ are calculated as in Hewings et al. (2001):

$$
e x_{i}^{r}= \begin{cases}1-\frac{1}{L Q_{i}^{r}} & L Q_{i}^{r}>1 \\ 0 & L Q_{i}^{r} \leq 1\end{cases}
$$

These export shares are the key linkage between sectors in a region to other sectors in other regions. The critical assumption for using this approach to determine export direction and intensity is that all local consumption of commodities that region $r$ exports are produced locally, which necessarily assumes away any cross-hauling effects; i.e., the simultaneous export and import of a given commodity in a given region (Isserman, 1980). Modifications of the $L Q$ to attend to cross-hauling effects have been suggested (Morrison and Smith, 1974; Round, 1983; Schaeffer and de Sá, 1996; Flegg et al., 1995). Further research could explore the sensitivity of the water multipliers using different $L Q$ formulations for determining interregional linkage.

Matrix multiplication of the column trade matrix and the direct requirements matrix of the 43-BEA region $(A)$ yields the multiregional direct requirements matrix of dimension $(43 \times 21)$ by $(21 \times 43)$ (Miller and Blair, 2009):

$$
A^{M}=C(I \otimes A)=\left[\begin{array}{cccc}
A^{1,1} & A^{1,2} & \ldots & A^{1,43} \\
A^{2,1} & A^{2,2} & \ldots & \vdots \\
\vdots & \vdots & \ldots & A^{42,43} \\
A^{43,1} & \ldots & A^{43,42} & A^{43,43}
\end{array}\right]
$$

where $I$ is a 43 by 43 identity matrix. Total multiregional water use impacts are calculated as:

$$
\Delta R=W\left(I-A^{M}\right)^{-1} C \Delta Y
$$

which is a $(43 \times 21)$ by 1 vector with each element indicating the total (direct and indirect) water use along the supply chain corresponding with the change in final demand. The matrix $W$ is a $(43 \times 21)$ by $(43 \times 21)$ diagonal with elements indicating how much water is withdrawn to meet a one-unit change in final demand; i.e., regional differences in the water use intensity 
of a sector. Regions with higher water multipliers require more water to meet the same level of final demand.

\subsection{Backward Linkage Index}

In terms of water withdrawal, backward linkages determine the capacity of sector $i$ to influence water use in sectors that provide inputs to sector $i$. In raw form, backward linkages are simply the column elements of matrix $H$ (see Henry and Bowen (1981));

$$
H=W\left(I-A^{M}\right)^{-1} C
$$

Following Yu et al. (2010), we use an ad hoc comparative index to generalize the influence of a sector on water use in an economy, given a change in final demand. The linkage index is

$$
L_{i}^{r}=\frac{\Delta R_{r i}}{\frac{1}{21 \times 43} \sum_{r} \sum_{i} \Delta R_{r i}}
$$

When $L_{i}^{r}>1$, a one-unit change in final demand in sector $i$, region $r$, will result in an above average increase in the water used by all sectors and regions. In other words, this index identifies important sector-region pairs in terms of the penetration that final demand shocks have on water withdrawal through the supply chain.

\section{RESULTS AND DISCUSSION}

The relative strength of interregional and intersectoral linkages affects the size of the water multiplier differently across BEA regions and sectors. Figure 5 compares sector-specific multipliers determined for each BEA region, absent interregional linkages, with multiregional water multipliers. The sector-by-region multipliers are included in Appendix Table II. Intersectoral and interregional spillover affects multiplier size. We tested if the ratio of the MRIO multiplier to the non-regional multiplier exceeded one. The average of the ratio was $2.69 \pm 0.11$ (mean \pm standard error), with a two-standard error confidence interval of $[2.47,2.91]$. The null hypothesis, $H_{0}: R_{M R I O}=R_{0}$, was tested for each ratio. The null was rejected for 773 sector-region pairs, of which 770 of the rejections (83 percent of 903) were above the upper confidence interval. There was no discernible regional pattern indicating where spillover affected calculation of water multipliers, but the distribution of regions with sector multipliers exceeding one was bimodal (see Table 2, rightmost column).

Sectors and BEA regions with higher water use coefficients have higher total water multipliers. The relative size of the water multipliers was generally largest for the utilities sector, except in regions where crop and livestock sectors withdrew more water (see Figure 6). Some BEA regions have relatively large water use coefficients mainly due to non-consumptive water withdrawals. Two notable examples are the livestock sector in Asheville, NC (BEA 10) and the utilities sector in Huntsville, AL (BEA 76) (see Figures 5, 6, and supporting data in Appendix Table 2). Several large trout farms withdraw surface water in BEA 10. These farms use raceways to divert and return water to the stream system with little consumptive 


\section{Figure 5: Comparison of Typical and Multiregional Multipliers (Diagonal Line is a 1:1 Ratio)}

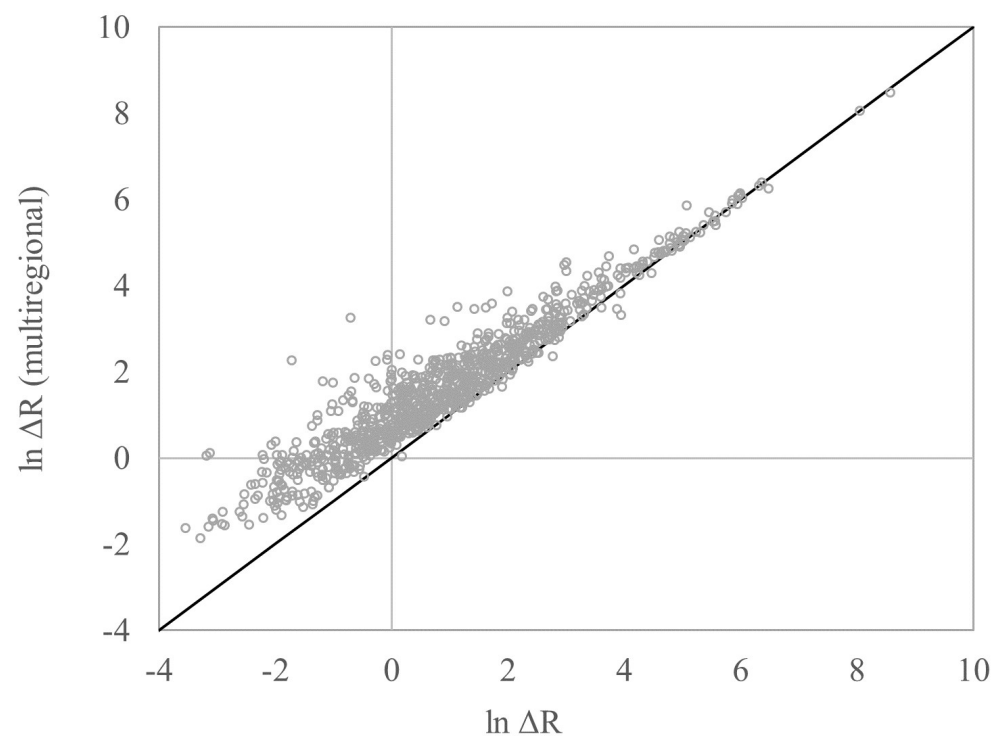

use. The Huntsville, AL BEA contains the Browns Ferry Nuclear plant, which is the second largest reactor in the US and represents 10 percent of the Tennessee Valley Authority's total generated capacity (Tennessee Valley Authority (TVA), 2018). Thus, much of the water withdrawn by the utilities sector in this BEA is for thermoelectric cooling, another largely non-consumptive use.

The multipliers are comparatively larger for the primary agriculture and utilities sectors. For crops, the largest water multiplier of 523 gal $\$^{-1}$ is for BEA 96 (Little Rock-North Little Rock-Pine Bluff, AR) (Appendix 2). This BEA region ranks first in water withdrawal as well as water withdrawn for irrigated agriculture, followed by Lake Charles-Jennings, LA (BEA 91), the Memphis, TN-MS-AR region (BEA 105), and Jackson-Yazoo City, MS (BEA 80). Changes in final demand will have a relatively larger impact on water withdrawn for irrigated crops and comparatively less impact on withdrawal in other sectors in these regions (see Figure 7).

\subsection{Direct and Indirect Effects}

Water multipliers can be decomposed by sector and region. Consider first the total water multiplier for crops in BEA 105 (Memphis, TN-MS-AR) (see Table 3). This region is dominated by row crop production and ranks second in the study area in terms of total industry output of primary agricultural products. A one-dollar increase in final demand for crops produced in the Memphis TN-MS-AR region requires 246 gallons of water from ground and surface sources. Significant contributions to the total water multiplier are from 


\section{Figure 6: Distribution of Multiregional EIO-LCA Water Multipliers (Pies are Share Indicating Relative Multiplier Size)}

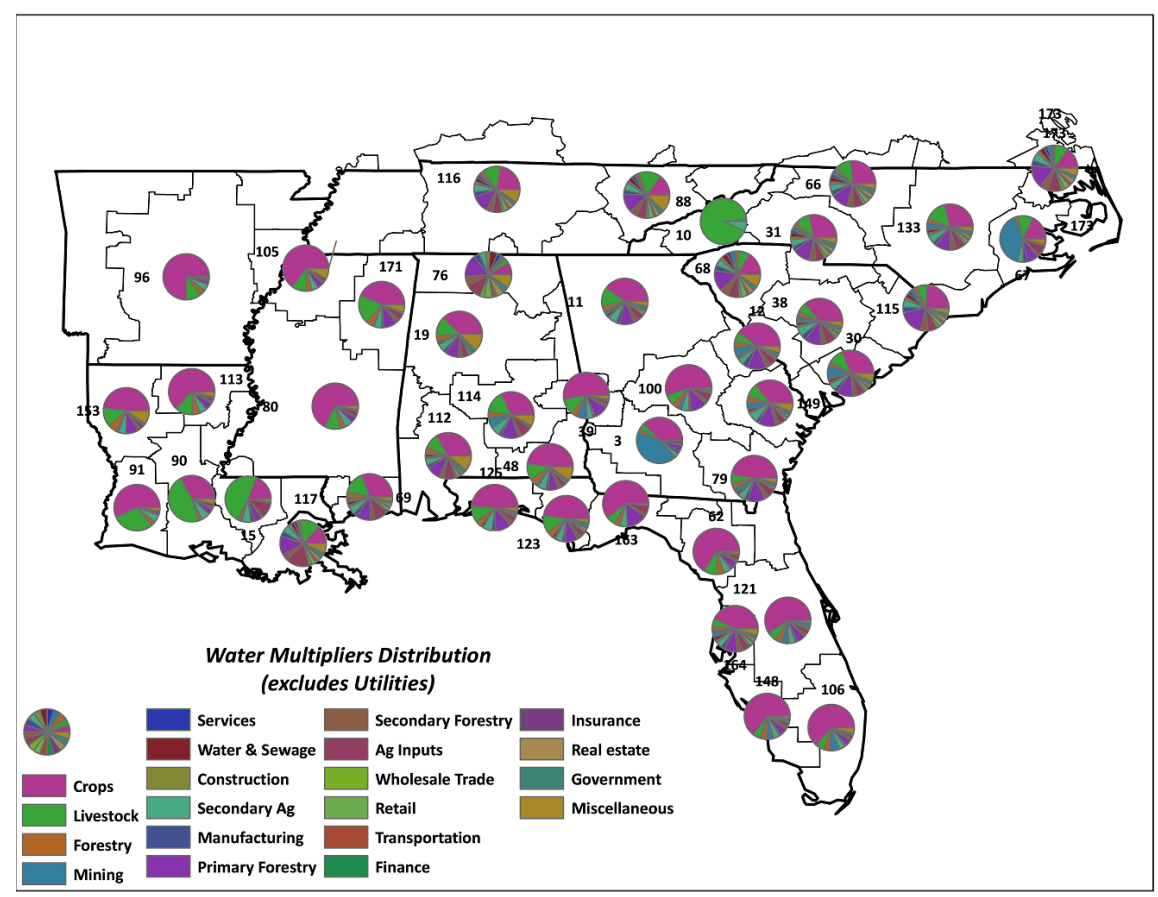

the increase in the production of crops in adjacent regions (Yazoo, MS and Little Rock, AR BEAs). About 80 percent of the multiplier is attributable to a direct effect; i.e., the water withdrawn for crop production in BEA 105 to meet the increase in final demand for crops produced in the region. For a one-dollar increase in final demand for crops in the Memphis BEA, 195 gallons of water withdrawn to meet this increase originates from ground and surface water in the same BEA region. The remainder of the multiplier tracks primarily to crop production in two other regions. Water withdrawn and used for crop production in BEA regions 80 (Yazoo, MS) and 96 (Little Rock, AR) accounts for 16 percent of the Memphis-Crop multiplier as indirect effects. The sum of the remaining 900 region-sector pairs accounts for the remainder. Aggregating over regions for each sector, primary crops production accounts for 99 percent of the crop water multiplier for the Memphis BEA. In other words, the 'footprint' appears concentrated in a specific region and a single sector.

Total industry output from the livestock sector in the Nashville, TN region (BEA 116) ranks ninth among livestock TVA across the BEA regions in the study area. For a onedollar increase in final demand for livestock products in the Nashville region, 26 gallons of water are withdrawn from ground and surface water sources, with 50 percent of this quantity directly originating from the livestock sector. Unlike the Memphis-Crop scenario, the impact of this shock extends through the crop sectors of the Memphis (TN), Yazoo (MS), and Little Rock (AR) BEA regions. Water multipliers for the non-agricultural sectors were generally much lower in relative magnitude than those for the primary agriculture and utility sectors. For example, a one-dollar increase in final demand for manufactured goods produced in the Atlanta BEA required 3.1 gallons of water.

(C)Southern Regional Science Association 2019. 


\section{Figure 7: Distribution of Multiregional EIO-LCA Water Multipliers (Pies are Share Indicating Relative Multiplier Size, Excluding Utilities.)}

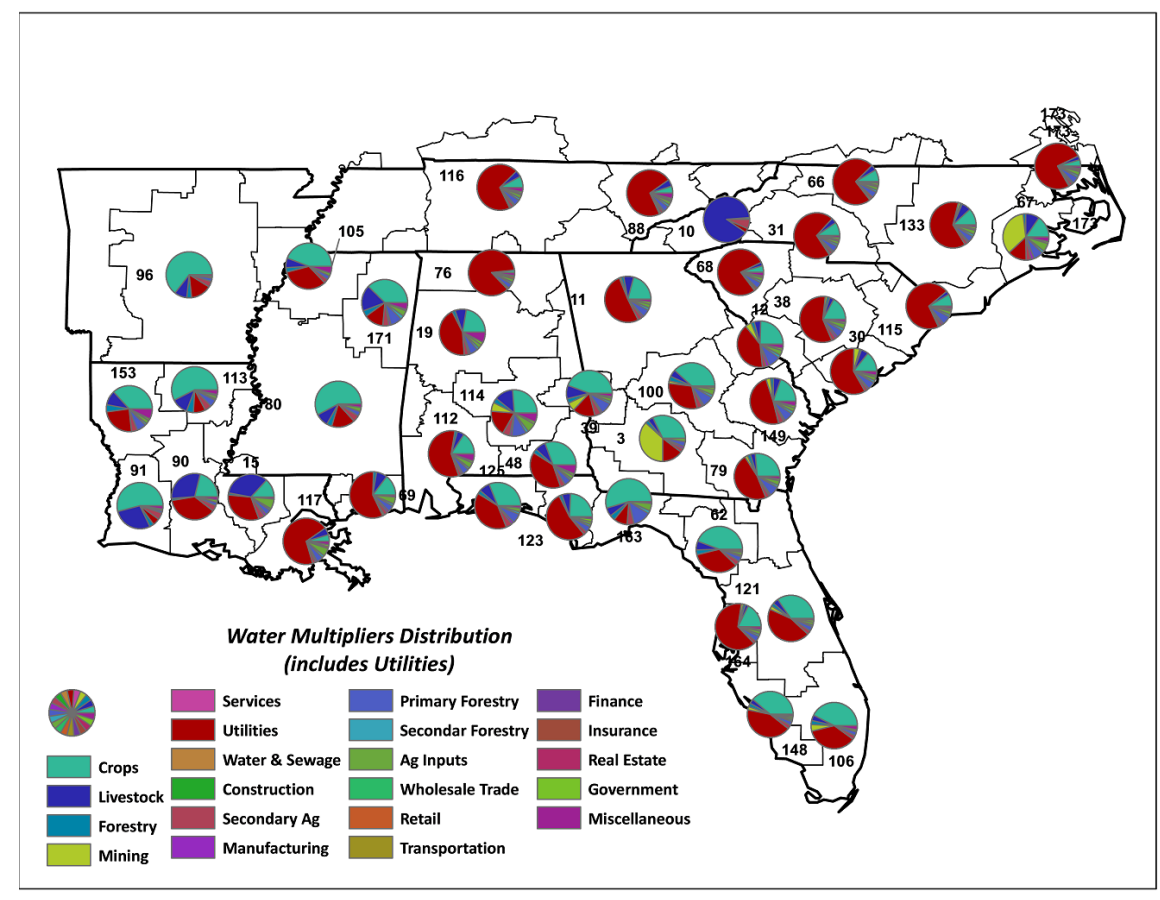

\subsection{Linkage Analysis}

Sector-region pairs with linkage index values exceeding one indicate key regions and economic activities affecting water withdrawal. The linkage ratio for the crop sector exceeded one in all 43 BEAs (see Table 4); i.e., a one-dollar increase in final demand for crop products generates an above-average increase in water withdrawal throughout the study areas economy. The utility sector was also a key water user in 40 of the 43 BEAs. These findings are similar to $\mathrm{Yu}$ et al. (2010), where the primary agriculture and utility/energy sectors were found to be key water consumers (directly and indirectly) based on strong backward linkages to other sectors and regions in China.

Across all 43 regions, the livestock and secondary agriculture sectors were the second and third key sectors in terms of the relative strength of the impact on water use as measured by the index. The construction, forestry, wholesale, transportation, finance, and insurance sectors all had index values of less than one in each region.

The Huntsville, AL BEA (BEA 76) exhibited linkage ratios exceeding one for 13 of its 21 economic sectors, which is atypical of other sectors' the linkage ratios. This pattern occurs because of the relatively large quantity of water withdrawn in this BEA for thermoelectric power generation, and the size and number of linkages between this sector, sectors in the BEA, and sectors in other sub-regions. 


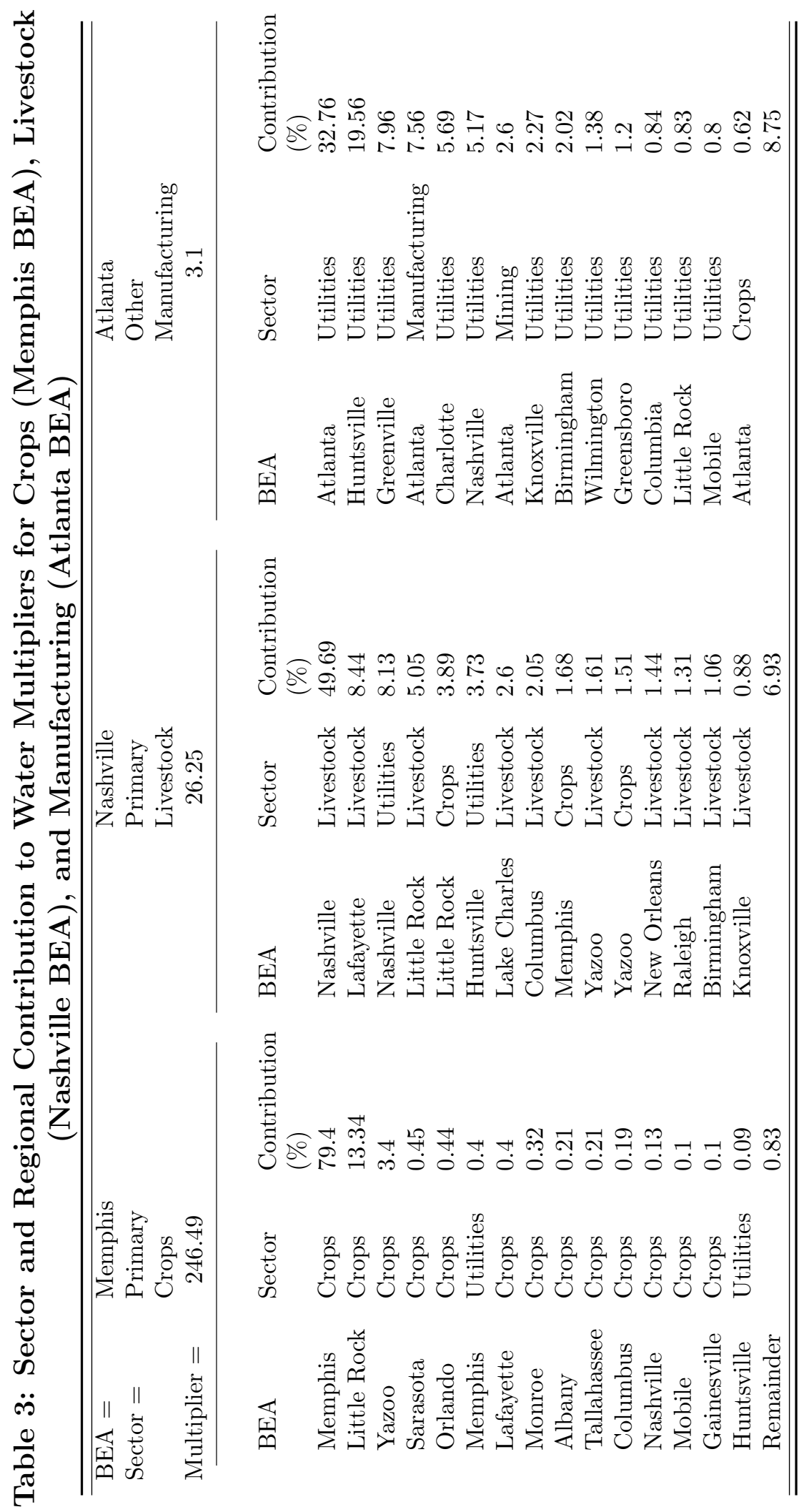

(c)Southern Regional Science Association 2019. 


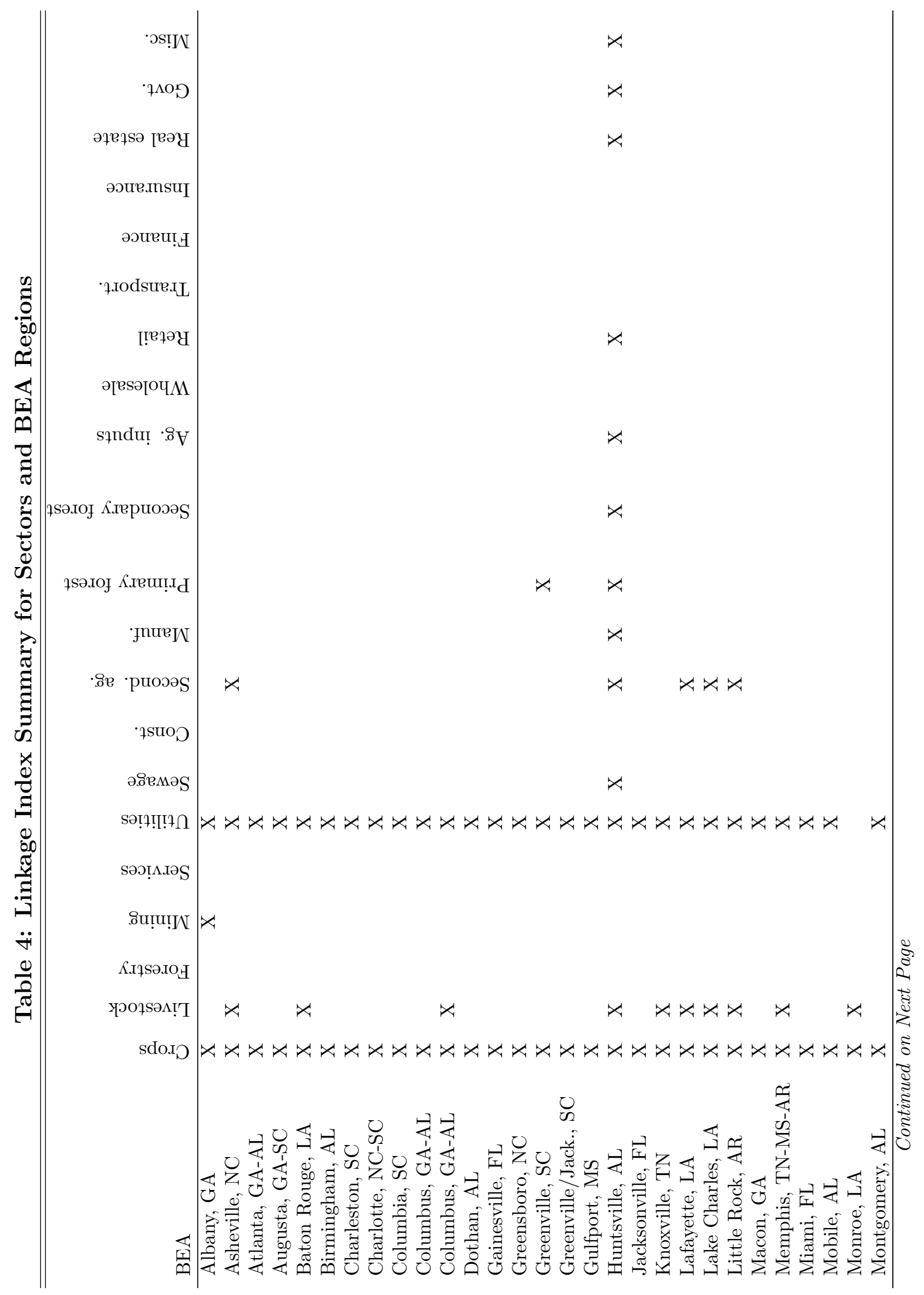

(c)Southern Regional Science Association 2019. 


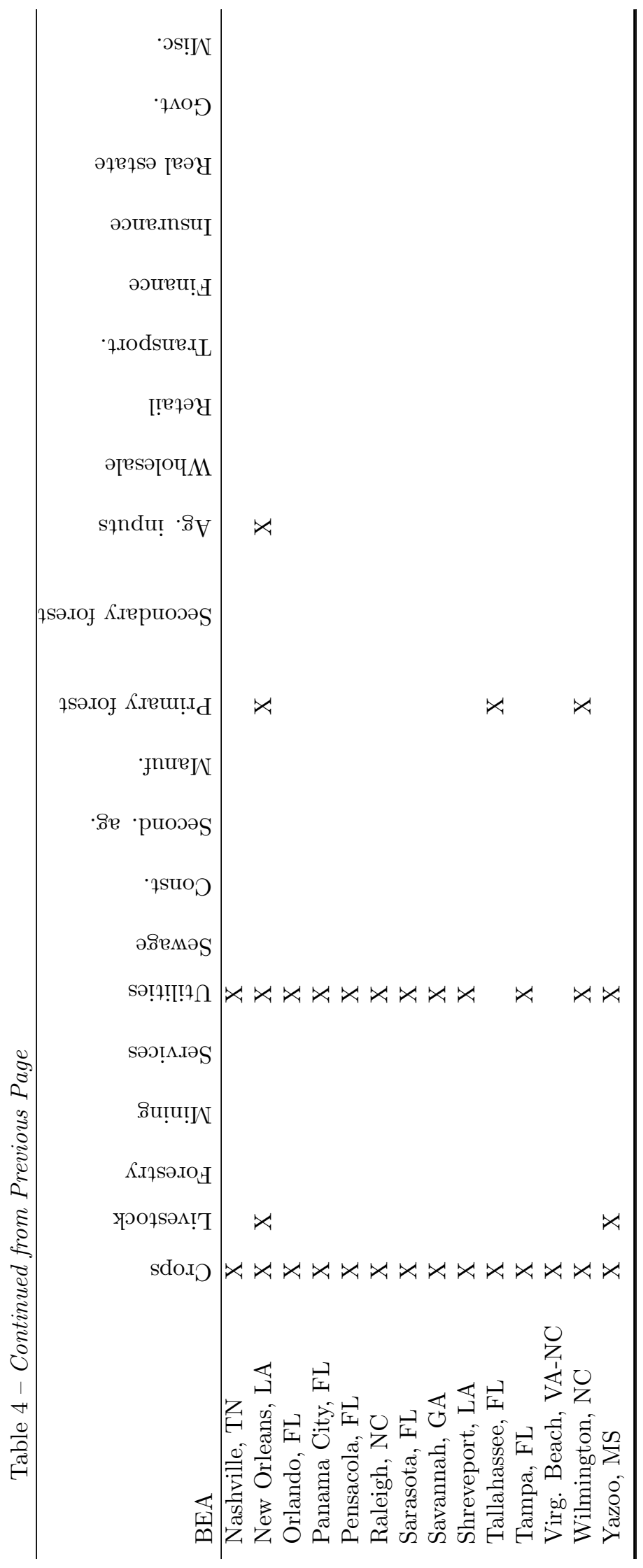

(C)Southern Regional Science Association 2019. 


\section{CONCLUSION}

The southeastern US' largest metropolitan areas are among the nation's leaders in terms of population growth and economic expansion. Demand for water resources to meet domestic and industrial energy needs and as an input into the production and distribution of goods and services will likely continue to trend upwards. The region is endowed with abundant ground and surface water; yet its economy remains susceptible to the impacts of drought. The 2007 and 2012 droughts revealed vulnerabilities in the region's ability to provide water to urban areas and to sustain agricultural and energy production. Arguably, the future of abundant water in the southeast may be in question, given likely changes in future climate patterns. State and local institutions could play a role in designing proactive measures to anticipate the allocation and conservation of water before resources are fully allocated and opportunities for cost-effective adaptation to these changing conditions expire. Future policies could encourage the allocation of water resources in relation to the marginal cost of its collection, storage, and provision towards the production of a good. Distributing water withdrawals by this criterion depends on the amount of water required to meet increases in demand for a good or service. The EIO-LCA model applied here is well suited for quantifying this multiplier using standard input-output procedures.

This research augmented a standard EIO-LCA model to accommodate the dimension of trade using a Multi-Regional IO model of the southeastern US. Results suggest that direct and indirect water requirements embedded in the production of goods and services are heterogeneous across the study region. Water multipliers estimated in the absence of interregional transfers underestimate the water required to meet increasing demand for goods and services. The resulting water footprint could inform the design of water management policies for local and regional institutions and open up the possibility for developing water-trading markets (Chapagain et al., 2006; Zhao and Jackson, 2016; Zhuo et al., 2016a; Chen et al., 2017).

There are caveats to this analysis. The primary data source for water only included county-level water withdrawal for a single period. The analysis therefore only pertains to water withdrawal, not consumptive use. Analyzing consumptive use would require disaggregated sector and regional data on return flow. In addition, the analysis only provides a snapshot of the southeastern economy and its water requirements. It is possible to model the effects of population growth, technological change, industry mix, and climate variability, but doing so would require multi-period transaction tables and water withdrawal data. The MRIO tables were not adjusted for cross-hauling effects. Therefore, the current results are conservative, lower bound estimates. Some approaches have been suggested to modify location quotients to accommodate cross-hauling effects, although these methods remain approximations. For example, other more computational and data intensive methods, such as doubly constrained gravity models, allow for cross-hauling. The IMPLAN system accounts for cross-hauling, but the trade matrices are proprietary. This analysis could be extended to determine how sensitive the water multipliers estimated using the simple location quotients are to the use of more complex computational approaches to defining inter-regional linkages.

Future research will extend the MRIO analysis to a linear programming model that maximizes gross regional product, subject to land, labor, and water availability constraints.

(c)Southern Regional Science Association 2019. 
By tightening water availability constraints and then re-solving the LP model, the marginal value of water specific to a given region and industry set can be determined. This model feature would introduce the possibility of examining the impacts of natural and humaninduced stressors on regional water availability, the economic burden shared between regions, and opportunities for the inter-regional transfer of water as a virtual and physical good. Goal programming methods or computable general equilibrium modeling could then be used to explore Pareto-efficient policies and their effect on inter-regional and intersectoral water transfers.

\section{REFERENCES}

Blackhurst, Michael, Chris Hendrickson, and Jordi Sels I Vidal. (2010) "Direct and Indirect Water Withdrawals for US Industrial Sectors," Environmental Science \& Technology, 44(6), 2126-2130.

Bohac, Charles E and Amanda K Bowen. (2012) "Water Use in the Tennessee Valley for 2010 and Projected Use in 2035," Last accessed May 2016 at https://www.nrc.gov/docs/ ML1733/ML17334A054.pdf.

Bureau of Economic Analysis. (2012) BEA Region. Last accessed August 2017 at https: //www.bea.gov/regional/docs/regions.cfm.

Cazcarro, Ignacio, Rosa Duarte, and Julio Sanchez Choliz. (2013) "Multiregional InputOutput Model for the Evaluation of Spanish Water Flows," Environmental Science \& Technology, 47(21), 12275-12283.

Chapagain, A K, A Y Hoekstra, and H H G Savenije. (2006) "Water Saving through International Trade of Agricultural Products," Hydrology and Earth System Sciences Discussions, 10(3), 455-468.

Chen, Weiming, Sanmang Wu, Yalin Lei, and Shantong Li. (2017) "China's Water Footprint by Province, and Inter-provincial Transfer of Virtual Water," Ecological Indicators, 74, 321-333.

Cicas, Gyorgyi, Chris T Hendrickson, Arpad Horvath, and H Scott Matthews. (2007) "A Regional Version of a US Economic Input-Output Life-cycle Assessment Model," International Journal of Life Cycle Assessment, 12(6), 365-372.

Easterling, David R, K E Kunkel, J R Arnold, T Knutson, A N LeGrande, L Ruby Leung, R S Vose, D E Waliser, and M F Wehner. (2017) "Precipitation Change in the United States," Climate Science Special Report: Fourth National Climate Assessment, Volume I.

Egilmez, Gokhan, Murat Kucukvar, and Omer Tatari. (2013) "Sustainability Assessment of US Manufacturing Sectors: An Economic Input Output-based Frontier Approach," Journal of Cleaner Production, 53, 91-102.

Flegg, Anthony T, C D Webber, and M V Elliott. (1995) "On the Appropriate Use of Location Quotients in Generating Regional Input-Output Tables," Regional Studies, 29(6), $547-561$.

Gross, Doug. (2018) Georgia Pushing To Move Tennessee Border. Last accessed July 2017 at https://patch.com/georgia/marietta/georgia-pushing-move-tennessee-border.

Hawkins, Gary. (2016) Georgia-Florida Water based Lawsuit. Last accessed July 2017 at https://site.extension.uga.edu/water/2016/11/georgia-florida-water-based-lawsuit/.

(C)Southern Regional Science Association 2019. 
Hendrickson, Chris, Arpad Horvath, Satish Joshi, and Lester Lave. (1998) "Economic InputOutput Models for Environmental Life-cycle Assessment," Environmental Science 86 Technology, 32(7), 184A-191A.

Hendrickson, Chris T, Lester B Lave, and H Scott Matthews. (2006) Environmental Life Cycle Assessment of Goods and Services: An Input-Output Approach. Resources for the Future.

Henry, Mark S and Ernie Bowen. (1981) "A Method for Estimating the Value of Water among Sectors of a Regional Economy," Journal of Agricultural and Applied Economics, $13(2), 125-132$.

Hewings, Geoffrey J D, Yasuhide Okuyama, and Michael Sonis. (2001) "Economic Interdependence within the Chicago Metropolitan Area: A Miyazawa Analysis," Journal of Regional Science, 41(2), 195-217.

Hoos, Anne B, Richard B Moore, Ana Maria Garcia, Gregory B Noe, Silvia E Terziotti, Craig M Johnston, and Robin L Dennis. (2013) "Simulating Stream Transport of Nutrients in the Eastern United States, 2002, using a Spatially-referenced Regression Model and 1: 100,000-scale Hydrography," U.S. Geological Survey.

Hutson, Susan S, M Carolyn Koroa, and C Michael Murphree. (2004) "Estimated Use of Water in the Tennessee River Watershed in 2000 and Projections of Water Use to 2030," U.S. Geological Survey, 3, 4302.

IMPLAN. (2013) IMPLAN Professional@: Users Guide, Analysis Guide, Data Guide. MIG. Isserman, Andrew M. (1977) "The Location Quotient Approach to Estimating Regional Economic Impacts," Journal of the American Institute of Planners, 43(1), 33-41.

Isserman, Andrew M. (1980) "Estimating Export Activity in a Regional Economy: A Theoretical and Empirical Analysis of Alternative Methods," International Regional Science Review, 5(2), 155-184.

Leontief, Wassily. (1970) "Environmental Repercussions and the Economic Structure: An Input-Output Approach," Review of Economics and Statistics, pp. 262-271.

Leontief, Wassily W. (1936) "Quantitative Input and Output Relations in the Economic Systems of the United States," Review of Economic Statistics, pp. 105-125.

Lindall, Scott A, Douglas C Olson, and Gregory S Alward. (2006) "Deriving Multi-regional Models Using the IMPLAN National Trade Flows Model," Journal of Regional Analysis and Policy, 36, 76-83.

Matthews, H Scott, Chris T Hendrickson, and Deanna H Matthews. (2015) Life Cycle Assessment: Quantitative Approaches for Decisions that Matter. Last accessed June 2016 at https://www.lcatextbook.com.

Maupin, Molly A, Joan F Kenny, Susan S Hutson, John K Lovelace, Nancy L Barber, and Kristin S Linsey. (2014) "Estimated use of water in the United States in 2010," .

McNulty, Steven G, Ge Sun, Erika C Cohen, J A Moore-Myers, D Wear, and W Jin. (2007) "Change in the Southern U.S. Water Demand and Supply over the Next Forty Years," Wetland and Water Resource Modeling and Assessment: A Watershed Perspective, pp. 43-56.

Melillo, Jerry M. (2014) Climate Change Impacts in the United States, Highlights: U.S. National Climate Assessment. Government Printing Office.

Menard, Jamey, Burton English, and Kim Jensen. (2013) Economic Impacts of Agriculture and Forestry in Tennessee 2011. Agri-industry Modeling

(C)Southern Regional Science Association 2019. 
\& Analysis Group Report RS 16-002, University of Tennessee, Knoxville. Last accessed April 2018 at https://ag.tennessee.edu/arec/Documents/ AIMAGPubs/EconomicContributionandImpactStudiesAgricultureandForestry/ EconControfAgandForinTN2013.pdf.

Miller, Ronald E and Peter D Blair. (2009) Input-Output Analysis: Foundations and Extensions. Cambridge University Press.

Mojica, Adrian. (2018) Georgia Lawmakers Want Tennessee to Give up Portion of Southern Border, Tennessee River. Last accessed September 2018 at https://katu.com/news/nation-world/ georgia-lawmakers-want-tennessee-to-give-up-portion-of-southern-border-tennessee-river.

Morrison, William Ian and Paul Smith. (1974) "Nonsurvey Input-Output Techniques at the Small Area Level: An Evaluation," Journal of Regional Science, 14(1), 1-14.

Mubako, Stanley, Sajal Lahiri, and Christopher Lant. (2013) "Input-Output Analysis of Virtual Water Transfers: Case Study of California and Illinois," Ecological Economics, 93, 230-238.

Mullinix, Heather. (2014) "City Seeks Timeline on Corps Study," Crossville Chronical. Last accessed at http://www.crossville-chronicle.com/news/local_news/ city-seeks-timeline-on-corps-study/article_8b877304-50a0-5c92-a1fa-b387fa850c64.html.

Norman, Jonathan, Alex D Charpentier, and Heather L MacLean. (2007) "Economic InputOutput Life-Cycle Assessment of Trade Between Canada and the United States," Environmental Science \& Technology, 5(41), 1523-1532.

Okadera, Tomohiro, Nobuhiro Okamoto, Masataka Watanabe, and Jaruwan Chontanawat. (2014) "Regional Water Footprints of the Yangtze River: An Interregional Input-Output Approach," Economic Systems Research, 26(4), 444-462.

OMB Bulletin No.15-01. (2015) Revised Delineations of Metropolitan Statistical Areas. Last accessed September 2018 at https://obamawhitehouse.archives.gov/sites/default/ files/omb/bulletins/2015/15-01.pdf.

Owen, Stephanie, Burton C English, Dayton Lambert, R. Jamey Menard, Lixia He-Lambert, and Chris Clark. (2017) "Determining Tennessee Water Use Coefficients," Department of Agricultural \& Resource Economics Research Series DRS-17-01. University of Tennessee Institute of Agriculture: Knoxville, Tennessee.

Owen, Stephanie Michaela. (2016). Estimating the Economic Value of Water for Agriculture and Other Industries in Tennessee. PhD thesis, University of Tennessee.

Park, W M, C D Clark, D M Lambert, and M D Wilcox Jr. (2007) "The Long-term Impacts of Retiree In-migration on Rural Areas: A Case Study of Cumberland County, Tennessee. Executive summary. Knoxville, Tennessee: The University of Tennessee," The Institute for Public Service and The Institute of Agriculture.

Robison, M Henry, Timothy Nadreau, and Jonathan Crapuchettes. (2015) EMSI IO Model Documentation. Last accessed at http://www.economicmodeling.com/2015/12/ 17/emsi-releases-input-output-technical-documentation/.

Round, Jeffery I. (1983) "Nonsurvey Techniques: A Critical Review of the Theory and the Evidence," International Regional Science Review, 8(3), 189-212.

Schaeffer, Roberto and André Leal de Sá. (1996) "The Embodiment of Carbon Associated with Brazilian Imports and Exports," Energy Conversion and Management, 37, 955-960. Seager, Richard, Alexandrina Tzanova, and Jennifer Nakamura. (2009) "Drought in the

(C)Southern Regional Science Association 2019. 
Southeastern United States: Causes, Variability over the Last Millennium, and the Potential for Future Hydroclimate Change," Journal of Climate, 22(19), 5021-5045.

Smith, Adam B and Richard W Katz. (2013) "U.S. Billion-dollar Weather and Climate Disasters: Data Sources, Trends, Accuracy, and Biases," Natural Hazards, 67(2), 387-410. Southern Environmental Law Center. (2008) Tri-state Water Wars (AL, GA, FL): Background. Last accessed at https://www.southernenvironment.org/cases-and-projects/ fact-sheets/tri-state-water-wars-al-ga-fl-background.

Southern Environmental Law Center. (2017) Advocating for the Long-Term Health of Two Major River Basins. Last accessed at https://www.southernenvironment.org/ cases-and-projects/tri-state-water-wars-al-ga-fl.

Tennessee Valley Authority (TVA). (2018) Browns Ferry Nuclear Plant. Last accessed August 2018 at https://www.tva.gov/Energy/Our-Power-System/Nuclear/ Browns-Ferry-Nuclear-Plant.

United States Office of Management and Budget. (2016) Micropolitan Statistical Areas, and Combined Statistical Areas, and Guidance on Uses of the Delineations of These Areas. Last accessed May 2016.

U.S. Census Bureau. (2017) Annual Estimates of the Resident Population for the United States, Regions, States, and Puerto Rico: April 1, 2010 to July 1, 2017 (NST-EST201701).

U.S. Department of Agriculture. (2013) 2012 Census of Agriculture: Farm and Ranch Irrigation Survey. Last accessed August 2018.

Velázquez, Esther. (2006) "An Input-Output Model of Water Consumption: Analyzing Intersectoral Water Relationships in Andalusia," Ecological Economics, 56(2), 226-240.

Vose, Russell, David R Easterling, Kenneth Kunkel, and Michael Wehner. (2017) "Temperature Changes in the United States," In Wuebbles, D J, D W Fahey K A Hibbard D J Dokken B C Stewart and T K Maycock, eds., Climate Science Special Report: Fourth National Climate Assessment. U.S. Global Change Research Program: Washington, DC, USA.

Yang, Hong and Alexander Zehnder. (2007) "Virtual Water: An Unfolding Concept in Integrated Water Resources Management," Water Resources Research, 43(12), 1-10.

Yu, Yang, Klaus Hubacek, Kuishuang Feng, and Dabo Guan. (2010) "Assessing Regional and Global Water Footprints for the UK," Ecological Economics, 69(5), 1140-1147.

Zhang, Chao and Laura Diaz Anadon. (2014) "A Multi-regional Input-Output Analysis of Domestic Virtual Water Trade and Provincial Water Footprint in China," Ecological Economics, 100, 159-172.

Zhao, Xueting and Randall W Jackson. (2016) "Chinas Inter-Regional Trade of Virtual WaterA Multi-Regional Input-Output Table Based Analysis," Water Economics and Policy, $2,1-28$.

Zhuo, La, Mesfin M Mekonnen, and Arjen Y Hoekstra. (2016a) "Consumptive Water Footprint and Virtual Water Trade Scenarios for China-With a Focus on Crop Production, Consumption and Trade," Environment International, 94, 211-223.

Zhuo, La, Mesfin M Mekonnen, and Arjen Y Hoekstra. (2016b) "The Effect of Inter-annual Variability of Consumption, Production, Trade and Climate on Crop-related Green and Blue Water Footprints and Inter-regional Virtual Water Trade: A Study for China (19782008)," Water Research, 94, 73-85.

(C)Southern Regional Science Association 2019. 
APPENDIX TABLE 1. Water Use Coefficients of 21 Aggregated Sectors and 43 BEAs $\left(\right.$ gal $\left.\$^{-1}\right)$

\begin{tabular}{|c|c|c|c|c|c|c|c|c|c|c|}
\hline $\mathrm{BEA}$ & Crop & Livestock & Forestry & Mining & Services & Utilities & $\begin{array}{l}\text { Water/ } \\
\text { sewage }\end{array}$ & Cons. & $\begin{array}{l}\text { Second. } \\
\text { Ag. }\end{array}$ & Manuf \\
\hline 3 & 87 & 4.31 & 0.01 & 141.15 & 0.03 & 20.5 & 0 & 0.01 & 0.52 & 0.53 \\
\hline 10 & 33 & 5175.25 & 0.02 & 2.59 & 0.14 & 101.54 & 0 & 0.07 & 1.84 & 0.19 \\
\hline 11 & 31 & 8.99 & 0.01 & 2.61 & 0.02 & 75.95 & 0 & 0.01 & 0.2 & 0.24 \\
\hline 12 & 48 & 4.34 & 0.09 & 10.97 & 0.33 & 33.11 & 0 & 0.13 & 0.62 & 3.11 \\
\hline 15 & 15 & 120.24 & 0.04 & 0.02 & 0.22 & 79.38 & 0 & 0.14 & 0.69 & 3.32 \\
\hline 19 & 38 & 11.48 & 0.01 & 0.9 & 0.03 & 76.4 & 0 & 0.02 & 0.49 & 0.2 \\
\hline 30 & 40 & 13.02 & 0.01 & 14.66 & 0.04 & 154.95 & 0 & 0.02 & 0.49 & 0.37 \\
\hline 31 & 38 & 13.28 & 0 & 3.67 & 0.01 & 303.58 & 0 & 0.01 & 0.14 & 0.19 \\
\hline 38 & 33 & 2.47 & 0.01 & 3.42 & 0.09 & 86.63 & 0 & 0.05 & 2.75 & 1.42 \\
\hline 39 & 74 & 10.78 & 0.03 & 11.93 & 0.06 & 3.79 & 0 & 0.04 & 1.53 & 0.39 \\
\hline 48 & 34 & 3.75 & 0 & 1.27 & 0.02 & 15.21 & 0 & 0.01 & 0.42 & 0.03 \\
\hline 62 & 88 & 4.14 & 0.01 & 0.29 & 0.01 & 47.22 & 0 & 0.01 & 0.41 & 0.09 \\
\hline 66 & 36 & 15.47 & 0 & 4.21 & 0 & 326.53 & 0 & 0 & 0 & 0.02 \\
\hline 67 & 19 & 12.69 & 0.02 & 69.67 & 0.22 & 0 & 0 & 0.12 & 2.29 & 1.05 \\
\hline 68 & 16 & 9.03 & 0 & 5.6 & 0.01 & 496.29 & 0 & 0.01 & 0.06 & 0.06 \\
\hline 69 & 13 & 11.62 & 0.03 & 1.2 & 0.16 & 125.22 & 0 & 0.06 & 0.25 & 0.66 \\
\hline 76 & 20 & 2.9 & 0.01 & 3.83 & 0.12 & 2710.59 & 0 & 0.09 & 4.12 & 1.09 \\
\hline 79 & 69 & 2.81 & 0.06 & 5.52 & 0.16 & 101.62 & 0 & 0.1 & 1.21 & 1.5 \\
\hline 80 & 234 & 14.12 & 0.01 & 2.13 & 0.11 & 33.61 & 0 & 0.06 & 3.67 & 0.7 \\
\hline 88 & 7 & 24.07 & 0 & 1.17 & 0.02 & 343.73 & 0 & 0.01 & 0.22 & 0.08 \\
\hline 90 & 132 & 254.29 & 0.01 & 0 & 0.03 & 210.59 & 0 & 0.02 & 0.14 & 0.32 \\
\hline 91 & 358 & 190.71 & 0.01 & 0 & 0.16 & 9.96 & 0 & 0.07 & 0.11 & 1.51 \\
\hline 96 & 585 & 52.88 & 0.02 & 5.67 & 0.1 & 80.7 & 0 & 0.06 & 1.84 & 0.82 \\
\hline 100 & 79 & 3.76 & 0.02 & 4.23 & 0.17 & 16.04 & 0 & 0.1 & 2.79 & 0.63 \\
\hline 105 & 242 & 23.45 & 0 & 3.23 & 0.03 & 134.07 & 0 & 0.02 & 0.07 & 0.29 \\
\hline 106 & 143 & 4.07 & 0 & 16.08 & 0 & 87.27 & 0 & 0 & 0.01 & 0.01 \\
\hline 112 & 53 & 15.02 & 0.01 & 0.84 & 0.09 & 240.24 & 0 & 0.05 & 0.12 & 1.8 \\
\hline 113 & 90 & 9.9 & 0.01 & 0.02 & 0.04 & 1.71 & 0 & 0.03 & 1.48 & 0.35 \\
\hline 114 & 26 & 13.4 & 0.03 & 12.35 & 0.13 & 2.19 & 0 & 0.08 & 3.38 & 0.14 \\
\hline 115 & 29 & 4.54 & 0.02 & 3.39 & 0.12 & 284.51 & 0 & 0.06 & 1.48 & 1.43 \\
\hline 116 & 5 & 15.38 & 0 & 2.17 & 0.06 & 319.86 & 0 & 0.04 & 0.97 & 0.43 \\
\hline 117 & 2 & 24.78 & 0.24 & 0.03 & 0.45 & 437.31 & 0 & 0.26 & 2.32 & 2.7 \\
\hline 121 & 98 & 3.41 & 0.01 & 7.36 & 0.02 & 98.17 & 0 & 0.01 & 0.22 & 0.14 \\
\hline 123 & 64 & 12 & 0 & 0 & 0 & 140.29 & 0 & 0 & 0 & 0.03 \\
\hline 125 & 54 & 8.84 & 0.06 & 0 & 0.3 & 58.26 & 0 & 0.14 & 2.82 & 1.88 \\
\hline 133 & 23 & 12.28 & 0 & 4.17 & 0.02 & 125.08 & 0 & 0.02 & 0.47 & 0.08 \\
\hline 148 & 149 & 3.09 & 0 & 8.73 & 0 & 119.59 & 0 & 0 & 0.04 & 0.01 \\
\hline 149 & 28 & 5.94 & 0.05 & 7.17 & 0.14 & 73.4 & 0 & 0.07 & 3.62 & 0.52 \\
\hline 153 & 50 & 5.76 & 0.01 & 0.49 & 0.07 & 25.77 & 0 & 0.03 & 1.78 & 0.23 \\
\hline 163 & 131 & 5.02 & 0.21 & 1.7 & 0.41 & 1.38 & 0 & 0.26 & 3.74 & 0.77 \\
\hline 164 & 63 & 1.56 & 0 & 5.2 & 0.01 & 217.89 & 0 & 0.01 & 0.04 & 0.09 \\
\hline 171 & 19 & 35.24 & 0.01 & 1.7 & 0.1 & 2.99 & 0 & 0.06 & 0.39 & 0.65 \\
\hline 173 & 13 & 10.34 & 0.03 & 3.98 & 0.13 & 339.88 & 0 & 0.08 & 1.55 & 0.32 \\
\hline
\end{tabular}

(C)Southern Regional Science Association 2019. 
APPENDIX TABLE 1 (Continued)

\begin{tabular}{|c|c|c|c|c|c|c|c|c|c|c|c|}
\hline BEA & $\begin{array}{l}\text { Prim. } \\
\text { Forest }\end{array}$ & $\begin{array}{l}\text { Second. } \\
\text { Forest }\end{array}$ & $\begin{array}{l}\text { Ag. In- } \\
\text { puts }\end{array}$ & Whole & Retail & Trans. & Finance & Insur. & $\begin{array}{l}\text { Real } \\
\text { Es- } \\
\text { tate }\end{array}$ & Govt. & Misc. \\
\hline 3 & 1.67 & 0.01 & 1.1 & 0.01 & 0.02 & 0.03 & 0 & 0 & 0.01 & 2.12 & 0.07 \\
\hline 10 & 3.06 & 0.1 & 15.45 & 0.04 & 0.08 & 0.12 & 0.02 & 0.01 & 0.11 & 1.97 & 6.83 \\
\hline 11 & 1.5 & 0.02 & 0.66 & 0.01 & 0.01 & 0.01 & 0 & 0 & 0.02 & 2.82 & 1.43 \\
\hline 12 & 13.99 & 0.09 & 3.79 & 0.07 & 0.15 & 0.12 & 0.03 & 0.01 & 0.15 & 2.98 & 5.43 \\
\hline 15 & 4.83 & 0.33 & 15.9 & 0.07 & 0.16 & 0.41 & 0.04 & 0.02 & 0.17 & 1.5 & 2.22 \\
\hline 19 & 0.6 & 0.04 & 0.32 & 0.01 & 0.02 & 0.02 & 0 & 0 & 0.02 & 4.13 & 18.11 \\
\hline 30 & 6.18 & 0.05 & 1.49 & 0.01 & 0.03 & 0.05 & 0.01 & 0 & 0.04 & 2.71 & 7.92 \\
\hline 31 & 1.03 & 0.01 & 0.16 & 0.01 & 0.01 & 0.01 & 0 & 0 & 0.01 & 4.19 & 3.16 \\
\hline 38 & 2.51 & 0.07 & 0.1 & 0.03 & 0.06 & 0.04 & 0.02 & 0 & 0.07 & 1.93 & 2.77 \\
\hline 39 & 7.91 & 0.11 & 1.16 & 0.02 & 0.04 & 0.03 & 0.02 & 0 & 0.04 & 1.84 & 2.43 \\
\hline 48 & 0.02 & 0.01 & 0.16 & 0 & 0.01 & 0.01 & 0 & 0 & 0.01 & 2.28 & 13.76 \\
\hline 62 & 0.03 & 0.01 & 0.35 & 0 & 0.01 & 0.01 & 0 & 0 & 0.01 & 1.31 & 0.72 \\
\hline 66 & 0.03 & 0 & 0.11 & 0 & 0 & 0 & 0 & 0 & 0 & 3.77 & 3.13 \\
\hline 67 & 8.4 & 0.2 & 9.19 & 0.07 & 0.14 & 0.21 & 0.03 & 0.02 & 0.15 & 1.18 & 5.5 \\
\hline 68 & 0.65 & 0.01 & 0.45 & 0 & 0.01 & 0.01 & 0 & 0 & 0.01 & 1.23 & 15.14 \\
\hline 69 & 1.6 & 0.11 & 3.82 & 0.03 & 0.07 & 0.11 & 0.02 & 0.01 & 0.07 & 0.65 & 1.54 \\
\hline 76 & 6.88 & 0.16 & 3.86 & 0.05 & 0.1 & 0.06 & 0.02 & 0.01 & 0.1 & 4.62 & 57.99 \\
\hline 79 & 11.34 & 0.09 & 4.36 & 0.05 & 0.11 & 0.22 & 0.03 & 0 & 0.13 & 1.9 & 3.81 \\
\hline 80 & 2.15 & 0.07 & 6.97 & 0.03 & 0.07 & 0.11 & 0.02 & 0.01 & 0.07 & 3.16 & 7.53 \\
\hline 88 & 0.57 & 0.01 & 1.07 & 0.01 & 0.01 & 0.01 & 0 & 0 & 0.01 & 2.36 & 20.39 \\
\hline 90 & 0.75 & 0.02 & 1.38 & 0.01 & 0.02 & 0.04 & 0 & 0 & 0.02 & 1.82 & 14.08 \\
\hline 91 & 2.14 & 0.09 & 4.62 & 0.04 & 0.08 & 0.1 & 0.02 & 0.01 & 0.07 & 1.46 & 14.47 \\
\hline 96 & 6.58 & 0.06 & 2.43 & 0.03 & 0.07 & 0.04 & 0.01 & 0 & 0.07 & 2.51 & 7.32 \\
\hline 100 & 10.98 & 0.1 & 0.36 & 0.05 & 0.11 & 0.12 & 0.02 & 0 & 0.1 & 2.74 & 0.44 \\
\hline 105 & 0.67 & 0.02 & 1.89 & 0.01 & 0.02 & 0.02 & 0 & 0 & 0.02 & 1 & 26.72 \\
\hline 106 & 0.02 & 0 & 0.07 & 0 & 0 & 0 & 0 & 0 & 0 & 1.73 & 9.1 \\
\hline 112 & 5.85 & 0.07 & 10.89 & 0.03 & 0.06 & 0.13 & 0.01 & 0.01 & 0.07 & 3.97 & 24.63 \\
\hline 113 & 5.52 & 0.03 & 1.04 & 0.01 & 0.03 & 0.02 & 0.01 & 0 & 0.03 & 2.75 & 7.79 \\
\hline 114 & 10.11 & 0.13 & 7.86 & 0.04 & 0.09 & 0.06 & 0.02 & 0.01 & 0.09 & 2.58 & 9.67 \\
\hline 115 & 14.03 & 0.07 & 0.46 & 0.03 & 0.07 & 0.09 & 0.02 & 0.01 & 0.09 & 2.41 & 3.77 \\
\hline 116 & 0.44 & 0.05 & 0.78 & 0.02 & 0.04 & 0.09 & 0.01 & 0 & 0.05 & 2.26 & 14.63 \\
\hline 117 & 8.06 & 0.42 & 40.85 & 0.14 & 0.3 & 1.16 & 0.07 & 0.03 & 0.34 & 5.97 & 14.55 \\
\hline 121 & 0.22 & 0.01 & 0.58 & 0 & 0.01 & 0.01 & 0 & 0 & 0.01 & 3.35 & 1.74 \\
\hline 123 & 0.03 & 0 & 0 & 0 & 0 & 0 & 0 & 0 & 0 & 5.74 & 2.35 \\
\hline 125 & 7.74 & 0.34 & 0 & 0.08 & 0.17 & 0.33 & 0.03 & 0.01 & 0.21 & 1.12 & 1.42 \\
\hline 133 & 0.52 & 0.02 & 2.35 & 0.01 & 0.02 & 0.02 & 0 & 0 & 0.02 & 2 & 1.91 \\
\hline 148 & 0 & 0 & 0.06 & 0 & 0 & 0 & 0 & 0 & 0 & 3.09 & 2.01 \\
\hline 149 & 3.6 & 0.11 & 0.29 & 0.04 & 0.08 & 0.16 & 0.02 & 0.01 & 0.09 & 2.68 & 6.15 \\
\hline 153 & 7.33 & 0.04 & 1.04 & 0.02 & 0.04 & 0.06 & 0.01 & 0 & 0.04 & 2.71 & 14.76 \\
\hline 163 & 34.43 & 0.37 & 11.49 & 0.14 & 0.3 & 0.48 & 0.06 & 0.02 & 0.32 & 1.63 & 1.6 \\
\hline 164 & 0.02 & 0.01 & 0.57 & 0 & 0.01 & 0.02 & 0 & 0 & 0.01 & 1.96 & 6.16 \\
\hline 171 & 8.45 & 0.04 & 0.03 & 0.03 & 0.07 & 0.04 & 0.02 & 0.01 & 0.05 & 1.83 & 8.31 \\
\hline 173 & 2.83 & 0.19 & 2.74 & 0.04 & 0.09 & 0.27 & 0.02 & 0 & 0.12 & 0.58 & 5.15 \\
\hline
\end{tabular}

(c)Southern Regional Science Association 2019. 
APPENDIX TABLE 2. Water Multipliers of 21 Aggregated Sectors and 43 BEAs (gal $\$^{-1}$ )

\begin{tabular}{|c|c|c|c|c|c|c|c|c|c|c|}
\hline$\overline{\mathrm{BEA}}$ & Crop & Livestock & Forestry & Mining & Services & Utilities & $\begin{array}{l}\text { Water/ } \\
\text { sewage }\end{array}$ & Construction & $\begin{array}{l}\text { Second. } \\
\text { Ag. }\end{array}$ & Manuf. \\
\hline 3 & 116.95 & 13.8 & 8.72 & 133.94 & 0.85 & 54.34 & 1.69 & 1.79 & 9.02 & 6.74 \\
\hline 10 & 64.78 & 4820.37 & 8.11 & 3.67 & 7.29 & 164.13 & 3.33 & 3.02 & 350.73 & 4.78 \\
\hline 11 & 49.71 & 16.56 & 4.69 & 3.23 & 1.2 & 122.23 & 2.15 & 1.39 & 7.58 & 3.1 \\
\hline 12 & 65.12 & 11.85 & 6.24 & 11.34 & 1.55 & 108 & 2.1 & 1.83 & 7.12 & 5.92 \\
\hline 15 & 47.98 & 122.72 & 5.91 & 1.13 & 1.61 & 116.24 & 2.86 & 1.98 & 15.84 & 5.72 \\
\hline 19 & 62.32 & 22.39 & 6.33 & 1.8 & 1.3 & 123.19 & 2.24 & 1.58 & 8.78 & 4.11 \\
\hline 30 & 54.37 & 19.84 & 4.78 & 15.43 & 2.03 & 222.72 & 3.63 & 2.21 & 8.11 & 4.41 \\
\hline 31 & 53.76 & 21.07 & 4.95 & 5.36 & 3.33 & 396 & 6.1 & 3.36 & 9.58 & 5.94 \\
\hline 38 & 48.83 & 9.8 & 4.73 & 4.26 & 1.68 & 169.41 & 2.85 & 1.88 & 8.8 & 4.59 \\
\hline 39 & 89.21 & 19.18 & 6.99 & 11.51 & 0.6 & 32.69 & 0.97 & 0.92 & 8.75 & 2.39 \\
\hline 48 & 74.21 & 17.96 & 7.33 & 1.87 & 1.01 & 94.06 & 1.8 & 1.18 & 8.74 & 2.41 \\
\hline 62 & 107.13 & 15.15 & 8.19 & 0.85 & 0.89 & 82.89 & 1.6 & 1.04 & 8.26 & 1.87 \\
\hline 66 & 51.3 & 23.07 & 4.8 & 6.07 & 3.66 & 439.42 & 6.75 & 3.63 & 9.8 & 6.12 \\
\hline 67 & 30.68 & 19.18 & 3.6 & 69.5 & 0.78 & 26.07 & 1.07 & 1.26 & 6.82 & 4.58 \\
\hline 68 & 35.58 & 17.96 & 4.28 & 7.95 & 4.82 & 594.21 & 8.86 & 4.73 & 10.32 & 7.85 \\
\hline 69 & 42.14 & 22.19 & 5.94 & 2.13 & 1.73 & 167.1 & 3.15 & 1.87 & 7.48 & 3.94 \\
\hline 76 & 68.15 & 30.32 & 9.78 & 15.12 & 24.92 & 3159.99 & 44.16 & 22.91 & 35.93 & 31.34 \\
\hline 79 & 83.94 & 11.08 & 6.72 & 6.2 & 1.63 & 150.45 & 2.61 & 1.89 & 8.58 & 4.42 \\
\hline 80 & 242.41 & 38.2 & 15.22 & 2.61 & 1.06 & 69.58 & 2.06 & 1.44 & 18.87 & 2.73 \\
\hline 88 & 29.86 & 31.37 & 3.85 & 3.12 & 3.76 & 449.07 & 6.83 & 3.72 & 10.13 & 6.54 \\
\hline 90 & 157.83 & 224.28 & 12.18 & 2.14 & 2.74 & 275.79 & 3.95 & 2.65 & 29.84 & 4.56 \\
\hline 91 & 362.94 & 186.47 & 20.6 & 1.06 & 1.05 & 31.9 & 1.44 & 1.45 & 32.82 & 3.1 \\
\hline 96 & 523.29 & 72.64 & 27.78 & 5.21 & 1.6 & 119.19 & 2.3 & 2.2 & 31.95 & 3.59 \\
\hline 100 & 95.59 & 12.56 & 7.68 & 4.58 & 1.07 & 76.79 & 1.57 & 1.32 & 9.75 & 2.81 \\
\hline 105 & 246.49 & 38.29 & 16.63 & 4.05 & 1.85 & 183.85 & 3.01 & 2.16 & 17.22 & 3.91 \\
\hline 106 & 153.76 & 13.78 & 10.56 & 16.52 & 1.28 & 130.3 & 2.32 & 1.52 & 10.17 & 2.78 \\
\hline 112 & 82.14 & 26.43 & 9.16 & 2.31 & 2.81 & 301.61 & 4.46 & 2.97 & 10.74 & 6.47 \\
\hline 113 & 157.75 & 31.72 & 13.45 & 1.13 & 0.53 & 24.04 & 1.47 & 0.86 & 12.96 & 1.57 \\
\hline 114 & 48.76 & 24.05 & 6.43 & 11.56 & 0.72 & 33.48 & 1.07 & 1.01 & 9.64 & 2.69 \\
\hline 115 & 43.96 & 12.86 & 4.91 & 5.03 & 3.28 & 369.8 & 5.73 & 3.38 & 9.51 & 6.73 \\
\hline 116 & 47.6 & 26.25 & 5.13 & 3.95 & 3.61 & 416.74 & 6.34 & 3.67 & 11.53 & 7.17 \\
\hline 117 & 35.83 & 40.91 & 5.73 & 2.42 & 5.3 & 553.65 & 7.41 & 5.05 & 15.03 & 10.25 \\
\hline 121 & 113.16 & 12.12 & 8.13 & 7.96 & 1.39 & 145.08 & 2.55 & 1.56 & 8.71 & 2.83 \\
\hline 123 & 86.06 & 21.69 & 7.79 & 1.05 & 1.73 & 190.81 & 3.13 & 1.86 & 8.85 & 3.19 \\
\hline 125 & 73.95 & 18.16 & 6.35 & 0.78 & 1.38 & 94.9 & 2.45 & 1.55 & 9.96 & 4.07 \\
\hline 133 & 36.38 & 19.37 & 3.51 & 5.05 & 1.7 & 189.15 & 3.07 & 1.78 & 7.22 & 3.29 \\
\hline 148 & 157.35 & 13.36 & 10.83 & 9.43 & 1.57 & 172.77 & 2.9 & 1.8 & 10.78 & 3.04 \\
\hline 149 & 47.71 & 12.84 & 5.3 & 7.66 & 1.36 & 119.7 & 2.18 & 1.48 & 9.16 & 3.15 \\
\hline 153 & 81.82 & 22.79 & 10.99 & 2.19 & 0.75 & 53.68 & 1.37 & 0.94 & 9.43 & 1.7 \\
\hline 163 & 141.52 & 15.35 & 9.89 & 2.05 & 1.03 & 24.94 & 0.93 & 1.33 & 12.34 & 2.24 \\
\hline 164 & 81.62 & 10.29 & 6.53 & 6.43 & 2.46 & 299.82 & 4.51 & 2.61 & 8.78 & 4.53 \\
\hline 171 & 87.92 & 42.2 & 9.51 & 2.16 & 0.7 & 32.02 & 1.36 & 1.07 & 10.09 & 3.23 \\
\hline 173 & 26.85 & 17.38 & 3.29 & 6.01 & 4.04 & 467.23 & 7.15 & 3.97 & 10.26 & 6.71 \\
\hline
\end{tabular}

(c)Southern Regional Science Association 2019. 
APPENDIX TABLE 2 (Continued)

\begin{tabular}{|c|c|c|c|c|c|c|c|c|c|c|c|}
\hline BEA & $\begin{array}{l}\text { Prim. } \\
\text { Forest }\end{array}$ & $\begin{array}{l}\text { Sec. } \\
\text { For- } \\
\text { est. }\end{array}$ & $\begin{array}{l}\text { Ag. In- } \\
\text { puts }\end{array}$ & Whole. & Retail & Trans. & Finance & Insure. & Real. & Govt. & Misc. \\
\hline 3 & 13.1 & 3.67 & 8.13 & 0.73 & 1.23 & 1.47 & 0.43 & 0.25 & 1.09 & 3.06 & 2.11 \\
\hline 10 & 18.95 & 9.6 & 22.89 & 2.7 & 4.94 & 2.68 & 1.84 & 0.98 & 2.88 & 4.62 & 12.91 \\
\hline 11 & 12.49 & 4.07 & 6.13 & 1.16 & 2.18 & 1.19 & 0.59 & 0.32 & 1.77 & 4.17 & 4.41 \\
\hline 12 & 22.1 & 5.22 & 9.37 & 1.24 & 2.19 & 1.5 & 0.72 & 0.38 & 1.83 & 4.21 & 7.65 \\
\hline 15 & 14.16 & 4.47 & 25.85 & 1.23 & 2.3 & 1.89 & 0.7 & 0.38 & 1.92 & 2.93 & 4.61 \\
\hline 19 & 15.66 & 4.76 & 7.51 & 1.19 & 2.29 & 1.41 & 0.71 & 0.36 & 1.81 & 5.43 & 20.62 \\
\hline 30 & 20.53 & 6.24 & 9.3 & 1.88 & 3.71 & 1.85 & 0.97 & 0.51 & 3.06 & 5.02 & 10.36 \\
\hline 31 & 23.59 & 8.78 & 12.61 & 3.06 & 6.34 & 2.69 & 1.5 & 0.79 & 5.17 & 8.01 & 7.25 \\
\hline 38 & 15.61 & 5.31 & 10.12 & 1.56 & 2.95 & 1.54 & 0.81 & 0.42 & 2.45 & 3.85 & 5.28 \\
\hline 39 & 16.05 & 3.32 & 4.67 & 0.54 & 0.86 & 0.76 & 0.34 & 0.2 & 0.73 & 2.51 & 4.55 \\
\hline 48 & 11.16 & 3.47 & 5.55 & 0.92 & 1.74 & 1.07 & 0.55 & 0.29 & 1.42 & 3.38 & 15.55 \\
\hline 62 & 8.52 & 2.87 & 4.55 & 0.81 & 1.54 & 0.83 & 0.46 & 0.26 & 1.32 & 2.43 & 2.52 \\
\hline 66 & 24.75 & 9.13 & 13.74 & 3.36 & 6.99 & 2.94 & 1.65 & 0.88 & 5.72 & 8.02 & 7.39 \\
\hline 67 & 13.84 & 3.23 & 12.01 & 0.58 & 0.87 & 1.19 & 0.39 & 0.22 & 0.83 & 2.43 & 6.59 \\
\hline 68 & 32.12 & 11.93 & 17.89 & 4.3 & 9.31 & 3.74 & 2.16 & 1.11 & 7.55 & 7.28 & 19.92 \\
\hline 69 & 13.48 & 4.61 & 13.66 & 1.46 & 2.88 & 1.64 & 0.76 & 0.42 & 2.38 & 2.63 & 4.4 \\
\hline 76 & 127.19 & 53.82 & 85.2 & 22.01 & 48.8 & 17.71 & 10.89 & 5.47 & 39.75 & 35.89 & 73.7 \\
\hline 79 & 21.73 & 5.43 & 10.27 & 1.41 & 2.72 & 1.61 & 0.77 & 0.41 & 2.28 & 3.6 & 6.03 \\
\hline 80 & 14.03 & 3.67 & 12.36 & 0.83 & 1.53 & 1.15 & 0.51 & 0.27 & 1.22 & 3.99 & 9.63 \\
\hline 88 & 26.13 & 9.61 & 15.04 & 3.38 & 7.16 & 3.02 & 1.76 & 0.9 & 5.82 & 6.99 & 23.98 \\
\hline 90 & 17.89 & 6.75 & 13.23 & 2.31 & 4.64 & 2.22 & 1.21 & 0.65 & 3.75 & 4.79 & 16.94 \\
\hline 91 & 10.27 & 2.99 & 8.98 & 0.6 & 1.05 & 0.97 & 0.45 & 0.24 & 0.78 & 2.08 & 15.66 \\
\hline 96 & 19.04 & 5.22 & 9.46 & 1.22 & 2.42 & 1.34 & 0.7 & 0.37 & 1.91 & 3.92 & 9.85 \\
\hline 100 & 19.71 & 4.33 & 9.8 & 0.91 & 1.63 & 1.07 & 0.52 & 0.29 & 1.35 & 3.66 & 2.68 \\
\hline 105 & 16.6 & 5.39 & 10.22 & 1.6 & 3.22 & 1.69 & 0.93 & 0.48 & 2.6 & 3.12 & 28.05 \\
\hline 106 & 10.16 & 3.68 & 5.4 & 1.16 & 2.27 & 1.21 & 0.65 & 0.34 & 1.92 & 3.24 & 10.69 \\
\hline 112 & 23.22 & 7.57 & 21.08 & 2.49 & 5.02 & 2.6 & 1.35 & 0.7 & 4.09 & 6.98 & 26.98 \\
\hline 113 & 13.86 & 2.99 & 5.18 & 0.42 & 0.69 & 0.68 & 0.3 & 0.15 & 0.54 & 3.14 & 9.37 \\
\hline 114 & 18.55 & 3.76 & 12.11 & 0.59 & 0.95 & 0.89 & 0.4 & 0.21 & 0.8 & 3.11 & 11.79 \\
\hline 115 & 32.24 & 9.4 & 12.36 & 2.96 & 6 & 2.73 & 1.46 & 0.78 & 4.88 & 6.13 & 7.47 \\
\hline 116 & 26.05 & 9.42 & 14.07 & 3.23 & 6.78 & 3 & 1.67 & 0.86 & 5.52 & 6.64 & 19.19 \\
\hline 117 & 36.53 & 12.9 & 45.86 & 4.61 & 9.28 & 5.01 & 2.38 & 1.27 & 7.65 & 11.44 & 19.4 \\
\hline 121 & 11.07 & 3.97 & 6.37 & 1.27 & 2.51 & 1.25 & 0.68 & 0.38 & 2.07 & 4.89 & 3.82 \\
\hline 123 & 15.81 & 5.1 & 7.75 & 1.61 & 3.2 & 1.58 & 0.83 & 0.44 & 2.58 & 7.34 & 5.21 \\
\hline 125 & 16.27 & 4.36 & 6.19 & 1.05 & 1.97 & 1.45 & 0.6 & 0.33 & 1.68 & 2.39 & 3.97 \\
\hline 133 & 13.2 & 5.05 & 9.19 & 1.62 & 3.15 & 1.49 & 0.8 & 0.43 & 2.63 & 4.07 & 4.31 \\
\hline 148 & 12.28 & 4.47 & 6.61 & 1.42 & 2.9 & 1.37 & 0.73 & 0.4 & 2.25 & 4.94 & 4.24 \\
\hline 149 & 16.19 & 4.49 & 6.27 & 1.19 & 2.21 & 1.36 & 0.66 & 0.35 & 1.86 & 4.02 & 8.26 \\
\hline 153 & 14.75 & 3.13 & 5.44 & 0.63 & 1.11 & 0.96 & 0.42 & 0.21 & 0.91 & 3.37 & 15.83 \\
\hline 163 & 33.1 & 5.32 & 13.79 & 0.68 & 1.12 & 1.18 & 0.46 & 0.25 & 1.01 & 2.25 & 3.35 \\
\hline 164 & 18.11 & 6.77 & 10.69 & 2.3 & 4.72 & 2.09 & 1.09 & 0.6 & 3.7 & 5.11 & 9.1 \\
\hline 171 & 19.13 & 5.78 & 9.7 & 0.56 & 0.9 & 0.88 & 0.37 & 0.2 & 0.71 & 2.4 & 11.14 \\
\hline 173 & 28.55 & 10.38 & 17.3 & 3.68 & 7.52 & 3.4 & 1.8 & 0.97 & 6.23 & 5.33 & 9.36 \\
\hline
\end{tabular}

Source: Authors' estimates.

(C)Southern Regional Science Association 2019. 